\title{
Heavy Winter Precipitation Events with Extratropical Cyclone Diagnosed by GPM Products and Trajectory Analysis
}

\author{
Morihiro SAWADA \\ Nagano management office, Kanto Branch, East Nippon Expressway Co., Ltd., Tokyo, Japan \\ and \\ Kenichi UENO \\ Faculty of Life and Environmental Sciences, University of Tsukuba, Tsukuba, Japan
}

(Manuscript received 28 March 2020, in final form 18 December 2020)

\begin{abstract}
Heavy precipitation events were identified during the cold seasons of 2014-2019 using two-day accumulated precipitation data at 137 stations of the Japan Meteorological Agency. The mechanisms for producing heavy precipitation regarding the structure of an occluding extratropical cyclone were analyzed using the products of the Dual-frequency Precipitation Radar (DPR) onboard the Global Precipitation Measurement (GPM) core satellite and trajectory analysis on the European Centre for Medium-range Weather Forecasts atmospheric reanalysis data. Upper-ranked events with heavy precipitation were predominantly caused by extratropical cyclones and were in mature stages. In the top 50 ranked events, three south-coast cyclones were nominated, and the relationships between developing the mesoscale precipitation system and airstreams were intensively diagnosed. Hourly precipitation changes at stations that recorded heavy precipitation were primarily affected by a combination of the warm conveyor belt (WCB), cold conveyor belt (CCB), and dry intrusion (DI). Wide-ranging stratiform precipitation east of the cyclone center was composed of low-level WCB over the CCB and upper WCB, and convective clouds around the cyclone center were associated with the upper DI over the WCB that provided an extreme precipitation rate at the surface, including the formation of a band-shaped precipitation system. Convective cloud activities also contributed to moist air advection over the stationary stratiform precipitation areas recognized as the upper WCB. DPR products also identified deep stratiform precipitation in the cloud-head area behind the cyclone center with mid-level (near-surface) latent heat release (absorption) with increased potential vorticity along the $\mathrm{CCB}$, making feedback intensification of the cyclone possible.
\end{abstract}

Keywords Global Precipitation Measurement; extratropical cyclone; heavy precipitation; conveyor belts; occluding stage

Citation Sawada, M., and K. Ueno, 2021: Heavy winter precipitation events with extratropical cyclone diagnosed by GPM products and trajectory analysis. J. Meteor. Soc. Japan, 99, 473-496, doi:10.2151/jmsj.2021-024.

Corresponding author: Kenichi Ueno, Faculty of Life and

Environmental Sciences, University of Tsukuba, Tsukuba,

Teno-dai 1-1-1, Tsukuba, Ibaraki 305-8572, Japan

E-mail: ueno.kenichi.fw@u.tsukuba.ac.jp

J-stage Advance Published Date: 29 January 2021

(C) The Author(s) 2021. This is an open access article published by the Meteorological Society of Japan under a Creative Commons Attribution 4.0 International (CC BY 4.0) license (https://creativecommons.org/licenses/by/4.0). 


\section{Introduction}

Winter monsoons or extratropical cyclones produce major winter precipitation in the Japanese islands. Extreme heavy snow covers along the Sea of Japan (SJ) because of winter monsoons have been studied from various viewpoints (Steenburgh and Nakai 2020). Extratropical cyclones passing along the south-coast of Japan, so-called south-coast cyclones (SCCs), also provide sporadic heavy snow cover along the Pacific and cause hazards, as occurred in February 2014 (Izumi et al. 2015). Mechanisms of heavy snow in the southeast United States (US) coast or the Pacific side of Japan have been revealed from various viewpoints (Bailey et al. 2003; Fujibe 1990; Yamazaki et al. 2015; Araki 2019). Increases in the water equivalent of snow cover because of heavy precipitation by cyclones produce avalanches or damage agricultural activities in mountainous areas (Moriyama et al. 2015; Matsushita and Ishida 2016).

From long-term perspectives, winter precipitation in western and central Japan has been increasing because of an increase in weather patterns with SCCs since the late 1980s (Ito and Ueno 2016). Precipitation intensity by extratropical cyclones should also increase because of global warming (Kodama et al. 2019). Ando and Ueno (2015) revealed that extratropical cyclones in the occluding stage tend to produce heavy precipitation in the inland district of Honshu using two-day accumulated precipitation totals. To consider the social impacts on the Pacific side of Japan or inland areas, it is critical to diagnose whether the mechanism of sporadic heavy precipitation on a time scale of one to two days could be induced because of the passage of cyclones.

Western countries, such as the US or England (Hobbs 1978) have investigated the formation of mesoscale precipitation systems regarding synoptic-scale cyclone structures. Three-dimensional structures and the evolution of the cyclone can be captured using a conveyor model composed of a combination of airstreams, such as the warm conveyor belt (WCB), cold conveyor belt (CCB), and dry intrusion (DI), with several types of fronts or convergences among them (Browning and Monk 1982; Browning 1986). Catto et al. (2010) or Schultz and Vaughan (2011) reviewed structures of the occluding stage with heavy precipitation in the cyclone, whereas Hart et al. (2017) also identified severe weather at the head of the intruding CCB. According to the lifecycle model of Shapiro and Keyser (1990), a bent-back front with CCBs and sting jet airstreams could also produce severe weather in the mature stage (Martinez-Alvarado et al. 2014). The DI can be identified using the moisture channel images of the geostationary satellite (Browning 1997), which is a key element causing upper layer instability and convection at the comma heads of winter cyclones in the occluding process (Rauber et al. 2014). Browning and Monk (1982) identified DI formation of the upper front over the WCB, and the lowering of mid-level static stability because of high potential vorticity (PV) intrusions by the DI could strengthen precipitation (Novak et al. 2010). According to Schemm and Wernli's (2014) idealized numerical experiments, the WCB's latent heat release over the surface bent-back front could accelerate the $\mathrm{PV}$ along the $\mathrm{CCB}$, and the low-level jet backward to the cyclone center could be strengthened indirectly. Hart et al. (2017) introduced the concept that the strengthening of low-level cyclonic circulation with high PV areas caused hazards because of intense winds. The maturing of the cyclone with the coupling of airstream structures and the precipitation system could strongly affect the increased winter precipitation in Japan, such that severe weather by the bent-back front was identified (Takano 2002). However, such evidence has not been fully captured and examined around Japan with observational confidences.

To observe the synoptic-scale structure of the cyclone and the enhancement of mesoscale precipitation systems, remote sensing is beneficial. For instance, Crespo and Posselt (2016) identified the deformation of the precipitation system from stratiform to convective types in the WCB using CloudSat images. Murphy et al. (2017) observed that different types of precipitation are distributed in comma-head clouds at the tip of the DI, such as the prevailing convective and stratiform regions in the south and the stratiform region in the north. Since 2014, the Global Precipitation Measurement (GPM) mission has started to observe tropical and midlatitude precipitation activity using the GPM Core Observatory (GPM-CO) satellite equipped with the GPM Microwave Imager and the Dual-frequency Precipitation Radar (DPR) (Hou et al. 2014). A field campaign was conducted in the US to explore the GPM-CO-DPR's (Skofronick-Jackson et al. 2017) performance, and GPM products were used for various aspects (Kobayashi et al. 2018; Akiyama et al. 2019; Yamaji et al. 2020). For instance, Naud et al. (2018) composed the distribution of the precipitation frequency and rate in oceanic extratropical cyclones and compared them with the CloudSat product. Zhang et al. (2020) revealed the structure of cyclonic precipitation in the northern Pacific storm track using 
GPM-DPR data in varying development stages.

The Japanese archipelago is composed of complex coastal lines and mountainous areas, occupying $\sim 70$ $\%$ of the land, where it is challenging for surface radar and gauge networks to capture the continuous distribution of precipitation types and intensity. GPM-CODPR data and products should diagnose three-dimensional structures of the precipitation system embedded in the extratropical cyclone. As a preliminary study, Sawada et al. (2019) used DPR data and identified that a combination of stratified and convective precipitation clouds in a winter extratropical cyclone could produce continuous substantial amounts of precipitation. This study first comprehensively identifies winter extratropical cyclones with behaviors that produced island-scale heavy precipitation since the beginning of the GPM mission. In several cases, the DPR-observed representative precipitation areas with airstreams identified using trajectory analysis of the fifth-generation European Centre for Medium-range Weather Forecasts (ECMWF) atmospheric reanalysis (ERA5) data (Hersbach et al. 2020). Then, the relationship between the mesoscale precipitation system and airstreams peculiar to the mature stage of cyclone structures was intensively revealed in the SCC with occluding stage cases.

\section{Analysis methods and data}

\subsection{Correction of precipitation amounts}

This study analyzed the cold season (NovemberApril) after March 2014, when the GPM mission started, until April 2019. Hourly precipitation data at 137 Japan Meteorological Agency (JMA) observation sites (Fig. 1) were used to identify heavy precipitation events. Because winter precipitation amounts are heavily underestimated by the under-collection of precipitation gauges (Goodison et al. 1998), the following steps were taken to correct underestimations for hourly data over $0.5 \mathrm{~mm} \mathrm{~h}^{-1}$. First, the precipitation phase (rain, snow, and sleet) was estimated using temperature and humidity data based on the methods proposed by Matsuo and Sasyo (1982) and Matsuo (1984). They proposed experimental formulas to estimate the threshold relative humidity of the precipitation phase as a function of temperature depending on coastal and inland areas (we defined the inland stations more than $10 \mathrm{~km}$ apart from the coast using crosses in Fig. 1). Next, when the phase was estimated as snow or sleet, the gauge catch ratio was calculated as a function of wind speed using the experimental formula proposed by Yoshida (1959). A parameter (m) in the experimental formula by Yoshida (1959) was set at 0.14 with

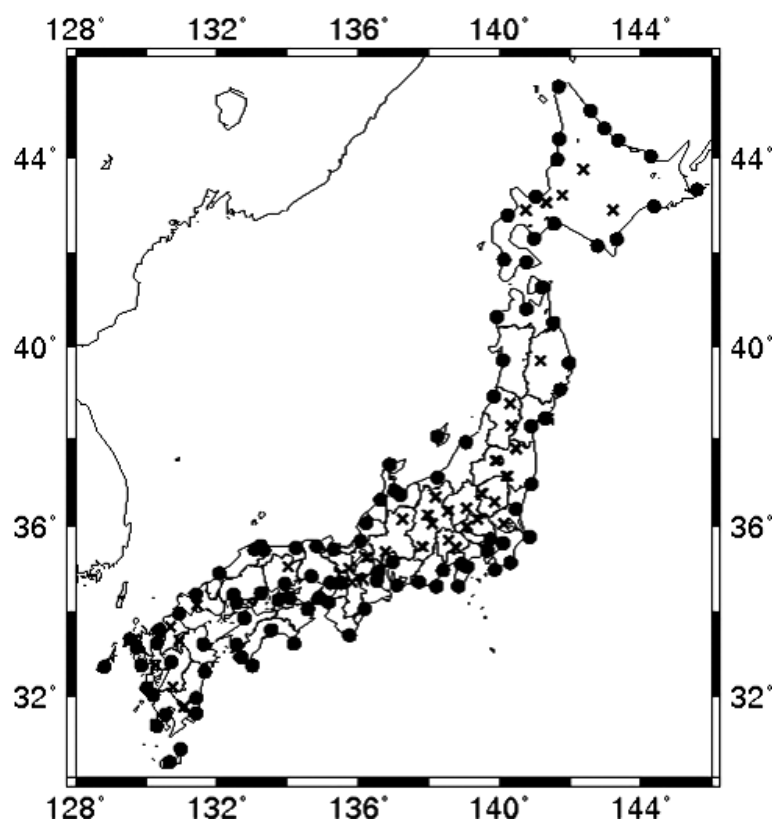

Fig. 1. Distribution of JMA observatories where precipitation data are used to identify extreme precipitation events, and discrimination of coastal $(\bullet)$ and inland $(\times)$ stations used for precipitation data correction.

gauge type RT-4, which is equipped with a heated antifreeze tank and widely used at JMA observatories.

Five years of uncorrected and corrected precipitation data of the accumulated precipitation distribution in January were compared (the figure is omitted). The amount of precipitation tends to increase by more than $10 \%$ in northern and northwestern Japan, and increases are more evident in the coastal areas of Hokkaido and the northwestern Tohoku region where wind speeds are higher.

\subsection{Designation of heavy precipitation events}

We designated heavy precipitation events, including heavy snowfall, based on two-day accumulated precipitation (TAP) amounts starting at 0 Japanese Standard Time (JST). TAP could include nocturnal precipitation continuing into successive days and is useful for evaluating the rain-on-snow load for building structure damage (Takahashi et al. 2016). Ando and Ueno (2015) also identified heavy winter precipitation cases using TAP only in the central areas of Honshu island. First, TAP data at each observation site were ranked with the date. If events with successive dates were found, the events after the second 
day's label were omitted. Then, points were awarded to the upper $10 \%$ of ranked events (dates), such as 100 to the first-ranked date, 99 for the second, until all dates were accounted for. Second, the points at all 137 sites were accumulated for each day during the analysis period of 967 days. Finally, the top 50 days ranked using the accumulated points were defined as heavy precipitation events. As the methods are based on the relative ranking of the TAP amount at each station as accumulated on an archipelago scale and not the ranking of areal-averaged absolute precipitation amount, heavy precipitation describes the nationwide occurrence of a comparatively extreme amount of one-to-two-day scale precipitation in this study.

Table 1 shows a list of 50 heavy precipitation events with TAP. Surface pressure patterns were classified based on the JMA's surface weather map considering the location of cyclone occurrence, such as winter monsoon (WM), with a strong pressure gradient over the SJ without cyclones, SCC, with a traveling cyclone along Pacific side coasts, cyclone from the SJ, with a traveling cyclone analyzed over the SJ, and DC, as latitudinally collated cyclone pairs. The order was different from the averaged TAP order, and most cases include a maximum point-measured TAP of more than $100 \mathrm{~mm}$. The order of the cases slightly changed after correcting the precipitation amounts, except for the top five cases; for instance, the 18th case was originally ranked 25 th. Although the precipitation amounts along the coastal areas along the SJ were corrected, a $\mathrm{WM}$ in the table) pressure pattern contributed to only 10 events $(20 \%)$ and were predominantly caused by passing extratropical cyclones. The frequency was greater from March to April because of the storm track's activation. They were not only by SCCs, but other types, such as a cyclone entering from the SJ or DC. For cyclones on the surface weather map identified in the areas of $120-150^{\circ} \mathrm{E}, 25-50^{\circ} \mathrm{N}, 24$ cases (almost half, marked $\bigcirc$ ) were accompanied by occluded fronts within $24 \mathrm{~h}$, and 14 other cases (marked $\triangle$ ) were also accompanied by occluded fronts outside the area after the cyclone center left Japan. Cyclones in the mature stage tended to provide nationwide heavy precipitation, correlating with the results of Ando and Ueno (2015), who only analyzed Honshu's Islands.

For cyclone events, the deepening rate (DR) of the central mean sea level pressure for two consecutive days was calculated using 6-hourly interval surface weather charts (the more intense cyclone center was chased in cases of DCs). In cases of DCs, miss-chasing to different cyclone systems were manually avoided and a more intensified cyclone center was chased to calculate the DR. In Table 1, the DR with and without the occluded front was $15.8 \mathrm{hPa}$ day $^{-1}$ and 5.0 $\mathrm{hPa}$ day $^{-1}$, respectively, indicating that cyclones tend to intensify with occlusion. Besides, only 17 cases were defined as explosive cyclones (hatched in the DR) according to Sanders and Gyakum's (1980) definition, indicating that explosive cyclones do not always produce nominated heavy precipitation. Cyclones with smaller DRs were also nominated. For instance, the DRs below $5 \mathrm{hPa}$ day $^{-1}$ account for 12 cases where half of the cyclones originated in the SJ.

\subsection{Matching DPR observation}

GPM-CO products of DPR Ver. 5 (Ver. 6 after November 2018) level-2 data (Iguchi et al. 2017; Seto et al. 2021) were used, including precipitation type/ intensity, echo-top height, and spectral latent heating (SLH) by Japan Aerospace Exploration Agency (JAXA) (2017) and Shige et al. $(2004,2007)$ to diagnose the three-dimensional structure of the precipitation system in the cyclone. The DPR is composed of Ku-band $(13.8 \mathrm{GHz})$ and $\mathrm{Ka}-$ band $(35.5 \mathrm{GHz})$ precipitation radars, and the dual-frequency ratio from these measurements are used to produce precipitation types including stratiform and convective precipitation (Awaka et al. 2016; Le et al. 2017). The frequency of GPM-DPR observations for precipitation areas associated with the cyclone system was counted as matching that of the DPR surface precipitation pattern based on weather charts and satellite images (right end line of Table 1), and 33 of 50 cases were matched. However, many of them did not fully crosscut the precipitation areas nor the surface front. Based on a case study by Sawada et al. (2019) and references of previous studies, we focused on three principal areas to be diagnosed regarding cyclone structure. These areas are the stratiform precipitation dominant area by WCB over CCB ahead of the cyclone (A), the occurrence of convective precipitation with the DI over the WCB near the cyclone center (B), and precipitation areas stretching from the northwest to west of the cyclone center according to the backward extension of an occluding front (C). The cyclone center at the DPR observation time was roughly determined based on the surface weather chart of JMA and satellite images of the Multi-functional Transport Satellite 2 (MTSAT-2) before April 2017 and Himawari geostationary weather satellite 8 (Himawari-8) after May 2017 (Yamamoto et al. 2020). Water vapor image (the third band of infrared radiation with a wavelength of $6.5-7.0 \mu \mathrm{m}$ for MTSAT-2, and the seventh band of infrared radiation 
Table 1. List of precipitation events up to the 50th. Surface pressure patterns (PPs) are classified as south-coast cyclone (SCC), cyclones from the Sea of Japan (SJ), double cyclones (DCs), and winter monsoons (WMs). The occluding level $(\mathrm{OL})$ corresponds to the occluding front analyzed $(\bigcirc)$, not analyzed $(\times)$, and analyzed out of the area $(\triangle)$ of $120-150^{\circ} \mathrm{E}$ and $25-50^{\circ}$ N. DPR observation areas (DOAs) are listed as A-C (no observation as 0), explained in Section 2.3, with an example in Fig. 3b. Explosive cyclones are hatched on a deepening rate (DR).

\begin{tabular}{|c|c|c|c|c|c|c|c|}
\hline Ranking & $\begin{array}{c}\text { Date } \\
(\mathrm{Y} / \mathrm{M} / \mathrm{D})\end{array}$ & 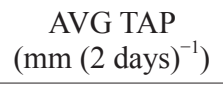 & $\begin{array}{c}\text { Max. TAP } \\
\left(\mathrm{mm}\left(2{\left.\text { days })^{-1}\right)}^{-1}\right.\right.\end{array}$ & PPs & $\mathrm{OL}$ & $\begin{array}{c}\text { DR } \\
\left(\mathrm{hPa} \mathrm{day}^{-1}\right)\end{array}$ & DOA \\
\hline $1(\alpha)$ & $2015 / 12 / 10$ & 52.8 & 280.0 & $\mathrm{SCC}$ & 0 & 12 & A \\
\hline 2 & $2018 / 4 / 24$ & 45.4 & 162.0 & $\mathrm{SCC}$ & $\bigcirc$ & 8 & 0 \\
\hline 3 & $2017 / 4 / 17$ & 44.0 & 172.5 & SJ & 0 & 9 & A \\
\hline 4 & $2018 / 3 / 8$ & 46.0 & 176.5 & $\mathrm{SJ}$ & $\triangle$ & 8 & 0 \\
\hline 5 & $2014 / 3 / 29$ & 34.4 & 134.0 & SJ & 0 & 20 & $\mathrm{~A}$ \\
\hline 6 & $2015 / 11 / 17$ & 36.4 & 161.0 & $\mathrm{SCC}$ & $\times$ & 8 & $\mathrm{~B}$ \\
\hline 7 & $2016 / 4 / 6$ & 32.2 & 144.5 & SJ & $\bigcirc$ & 4 & B \\
\hline 8 & $2016 / 1 / 29$ & 32.5 & 108.5 & $\mathrm{SCC}$ & $x$ & 6 & A \\
\hline $9(\beta)$ & $2018 / 3 / 21$ & 29.7 & 132.0 & $\mathrm{SCC}$ & $\bigcirc$ & 9 & $\mathrm{~B}+\mathrm{C}$ \\
\hline 10 & $2014 / 3 / 13$ & 33.5 & 337.0 & SCC & $\triangle$ & 20 & 0 \\
\hline $11(\gamma)$ & $2019 / 3 / 10$ & 31.4 & 102.0 & $\mathrm{SCC}+\mathrm{WM}$ & $\bigcirc$ & 25 & $\mathrm{C}$ \\
\hline 12 & $2015 / 3 / 9$ & 36.1 & 149.7 & DC & $\bigcirc$ & 27 & $\mathrm{C}$ \\
\hline 13 & $2016 / 12 / 13$ & 30.1 & 113.5 & $\mathrm{DC}$ & $\bigcirc$ & 22 & 0 \\
\hline 14 & $2016 / 2 / 20$ & 32.2 & 187.5 & DC & $\triangle$ & 22 & 0 \\
\hline 15 & $2016 / 2 / 13$ & 32.8 & 178.0 & $\mathrm{SJ}+\mathrm{WM}$ & $\triangle$ & 18 & A \\
\hline 16 & $2019 / 4 / 29$ & 29.9 & 237.5 & SCC & $\triangle$ & 8 & $\mathrm{~A}+\mathrm{B}$ \\
\hline 17 & $2015 / 3 / 18$ & 31.2 & 197.5 & SJ & $x$ & 2 & A \\
\hline 18 & $2016 / 1 / 18$ & 31.6 & 106.4 & $\mathrm{DC}+\mathrm{WM}$ & $\bigcirc$ & 21 & $\mathrm{~A}+\mathrm{B}$ \\
\hline 19 & $2016 / 4 / 27$ & 28.7 & 69.0 & SCC & $\bigcirc$ & 13 & $\mathrm{C}$ \\
\hline 20 & $2018 / 2 / 28$ & 28.6 & 138.0 & $\mathrm{DC}+\mathrm{WM}$ & $\bigcirc$ & 20 & 0 \\
\hline 21 & $2018 / 4 / 14$ & 29.3 & 162.5 & SJ & 0 & 13 & $\mathrm{~A}+\mathrm{B}$ \\
\hline 22 & $2018 / 3 / 4$ & 27.6 & 93.5 & SJ & $x$ & 0 & $\mathrm{~A}+\mathrm{B}$ \\
\hline 23 & $2015 / 11 / 14$ & 28.6 & 200.5 & $\mathrm{DC}$ & $\triangle$ & 14 & A \\
\hline 24 & $2016 / 4 / 21$ & 29.8 & 163.0 & SJ & $\times$ & 4 & $\mathrm{~A}$ \\
\hline 25 & $2017 / 4 / 10$ & 29.3 & 153.0 & SCC & $\bigcirc$ & 11 & $\mathrm{C}$ \\
\hline 26 & $2016 / 12 / 22$ & 31.0 & 116.5 & $\mathrm{SJ}+\mathrm{WM}$ & $\triangle$ & 12 & A \\
\hline 27 & $2016 / 3 / 9$ & 24.2 & 128.5 & SCC & $\times$ & 0 & $\mathrm{C}$ \\
\hline 28 & $2015 / 4 / 13$ & 25.5 & 327.0 & SCC & $\bigcirc$ & 5 & $\mathrm{C}$ \\
\hline 29 & $2015 / 1 / 14$ & 24.4 & 88.5 & SCC & $\bigcirc$ & 17 & 0 \\
\hline 30 & $2014 / 11 / 25$ & 23.8 & 112.5 & $\mathrm{DC}$ & $\triangle$ & 5 & $\mathrm{C}$ \\
\hline 31 & $2015 / 4 / 19$ & 28.2 & 106.0 & $\mathrm{SJ}$ & $\triangle$ & 7 & $\mathrm{~B}$ \\
\hline 32 & $2015 / 3 / 1$ & 25.1 & 73.5 & $\mathrm{DC}$ & $\bigcirc$ & 16 & $\mathrm{C}$ \\
\hline 33 & $2014 / 4 / 29$ & 24.7 & 302.5 & SJ & $\times$ & 0 & A \\
\hline 34 & $2019 / 4 / 9$ & 23.3 & 97.0 & SCC & $\bigcirc$ & 7 & 0 \\
\hline 35 & $2014 / 12 / 16$ & 28.9 & 170.4 & $\mathrm{DC}+\mathrm{WM}$ & $\bigcirc$ & 45 & $\mathrm{~A}+\mathrm{B}$ \\
\hline 36 & $2014 / 4 / 3$ & 24.3 & 121.5 & $\mathrm{DC}+\mathrm{WM}$ & $\bigcirc$ & 21 & 0 \\
\hline 37 & $2015 / 4 / 3$ & 20.3 & 85.5 & SJ & $\triangle$ & 4 & $\mathrm{~B}$ \\
\hline 38 & $2016 / 12 / 26$ & 21.2 & 97.5 & $\mathrm{SJ}$ & $\triangle$ & 20 & 0 \\
\hline 39 & $2015 / 11 / 8$ & 22.4 & 115.5 & SJ & $x$ & 8 & 0 \\
\hline 40 & $2016 / 4 / 3$ & 21.5 & 139.5 & SCC & $x$ & 12 & $\mathrm{~A}+\mathrm{B}$ \\
\hline 41 & $2015 / 11 / 26$ & 18.7 & 151.2 & $\mathrm{DC}+\mathrm{WM}$ & $\times$ & 14 & 0 \\
\hline 42 & $2014 / 3 / 20$ & 19.8 & 104.5 & SCC & $\bigcirc$ & 21 & $\mathrm{~A}+\mathrm{B}+\mathrm{C}$ \\
\hline 43 & $2018 / 12 / 3$ & 21.7 & 186.0 & SJ & $\triangle$ & 12 & $\mathrm{~A}+\mathrm{B}$ \\
\hline 44 & $2017 / 4 / 6$ & 21.2 & 132.0 & SCC & $\times$ & 2 & 0 \\
\hline 45 & $2018 / 1 / 8$ & 23.3 & 122.5 & $\mathrm{DC}+\mathrm{WM}$ & 0 & 28 & A \\
\hline 46 & $2015 / 4 / 10$ & 18.3 & 105.5 & SCC & $x$ & 4 & 0 \\
\hline 47 & $2014 / 12 / 20$ & 23.7 & 105.0 & $\mathrm{DC}$ & $\bigcirc$ & 32 & 0 \\
\hline 48 & $2016 / 11 / 26$ & 19.0 & 101.0 & SCC & $\triangle$ & 4 & A \\
\hline 49 & $2014 / 12 / 1$ & 16.4 & 89.0 & $\mathrm{DC}+\mathrm{WM}$ & $\bigcirc$ & 21 & $\mathrm{~A}+\mathrm{B}+\mathrm{C}$ \\
\hline 50 & $2016 / 4 / 13$ & 20.3 & 155.0 & DC & $\triangle$ & 12 & 0 \\
\hline
\end{tabular}


with a wavelength of $3.9 \mu \mathrm{m}$ for Himawari-8) is used to identify the distribution of the DI. Then, areas A-C were allocated based on the precipitation distribution captured using JMA composite weather radar echoes data, the DPR image, and the location of the cyclone center. The observation frequencies of DPR corresponding to areas $\mathrm{A}-\mathrm{C}$ were 21,17 , and 10 , respectively (indicated in the rightmost column in Table 1). An example of the areas' locations will be introduced in Section 3. Finally, we chose three mature cases $(\alpha-\gamma)$ to intensively observe precipitation areas A-C as introduced in Section 4.

\subsection{Identification of conveyor belts using trajectory analysis}

Browning (1990) identified three major airstreams (conveyor belts), such as the WCB, characterized by ascending warm and moistened airstream in the warm sector, the CCB, characterized by low-level cold air mass intruding from the east to the back of the cyclone center ahead of the WCB, and the DI coming down from the upper level to the cyclone center, characterized by a dry air mass by isentropic analysis. Trajectory analysis is an objective method for identifying airstreams and cataloging them according to the conveyor belt (Wernli and Davies 1997; Schemm and Wernli 2014). This study performed trajectory analysis on ERA5 hourly objective analysis data with $0.25^{\circ}$ intervals from the reference grids in the DPR observation area (column). The calculation was performed using 18 constant pressure levels (surface to $300 \mathrm{hPa}$ ) using hourly horizontal and vertical wind vector data. Calculations forwarded for $24 \mathrm{~h}$ and backward for $48 \mathrm{~h}$ were done using original programs with references to LANGRANTO software methods (Sprenger and Wernli 2015). The ERA5 data cannot resolve 10 $\mathrm{km}$ scale cloud cells observed by DPR. However, it improved large-scale cloud and precipitation schemes (including the diurnal cycle) by changing the convection parametrization or using modified convective available potential energy (CAPE) closure with assimilating multiple observed data, such as using infrared radiances from geostationary satellites (Hersbach et al. 2020). In this study, surface wind, CAPE, and vertical integration of the divergence of moisture flux (VIWVD) produced in the ERA5 data are used to diagnose the characteristics of airmass associated with air streams.

According to Schemm and Wernli (2014), the WCB was defined using trajectories starting below $800 \mathrm{hPa}$ and increasing to more than $500 \mathrm{hPa}$ for $48 \mathrm{~h}$. The CCB was also defined using trajectories below 800
$\mathrm{hPa}$ with maximum PVs of more than 2 potential vorticity units (PVU) for $48 \mathrm{~h}$. In this study, as most trajectories started from the DPR-observed cross-section in the precipitation system, traditional tracking criteria were modified to increase the airstream candidates. First, the pressure level raising criterion for the WCB was modified to $400 \mathrm{hPa}$. For the CCB criterion, cyclone cases in this study did not always accompany low-level high PV, such as more than 2 PVU. Hirata et al. (2016) defined a low-level strong zonal easterly airstream in the west or north of a cyclone center as the CCB in SCC cases, and the contribution of water vapor transportation into the bent-back front because of $\mathrm{CCB}$ deformation by moistening over warm currents was revealed. This study also focused on the direction of air parcel movement, and low-level trajectories below $800 \mathrm{hPa}$ moving from east to west relative to the cyclone center were defined as the CCB. Raveh-Rubin (2017) defined the trajectory as DI when it started above $600 \mathrm{hPa}$ and descended by more than $400 \mathrm{hPa}$ for $48 \mathrm{~h}$. Many parcels chased by the trajectory analysis in the following section's cases were near the cyclone center where the synoptic-scale ascending motion prevailed, and their altitude did not change by more than $400 \mathrm{hPa}$. To identify the dry air parcel intrusion, this study additionally included the trajectories if the average relative humidity during air parcel travel was less than $50 \%$, with no limit on descending pressure differences.

Figure 2 shows differences in airstreams depending on the pressure change and humidity with backward/ forward routes to confirm the performance trajectory analysis using the previously mentioned categories. Air parcels at 950,750 , and $300 \mathrm{hPa}$ in the domain of DPR observation in the ninth case, which will be introduced in Section 4.2 as case $\beta$, are chased. According to a scattering diagram (Fig. 2a), three airstreams were divided, namely the moist WCB with an upward motion, the moist CCB without pressure (level) changes, and the dry DI with descending motion. The WCB gathered from two directions east ahead of the cyclone center and south from the back of the cyclone center and passed northward (Fig. 2b). The $\mathrm{CCB}$ entered from the northeast or the north around the central mountain areas and flowed out to the south with cyclonic rotation (Fig. 2c). The DI flowed from the southwest to the northeast chasing as a cyclone center movement (Fig. 2d). The demonstrated features corresponded well with the diagrams of previous studies (Schultz and Vaughan 2011), except that the trajectories categorized as WCB intruded from the east along the $\mathrm{CCB}$ front were unique, and details are 

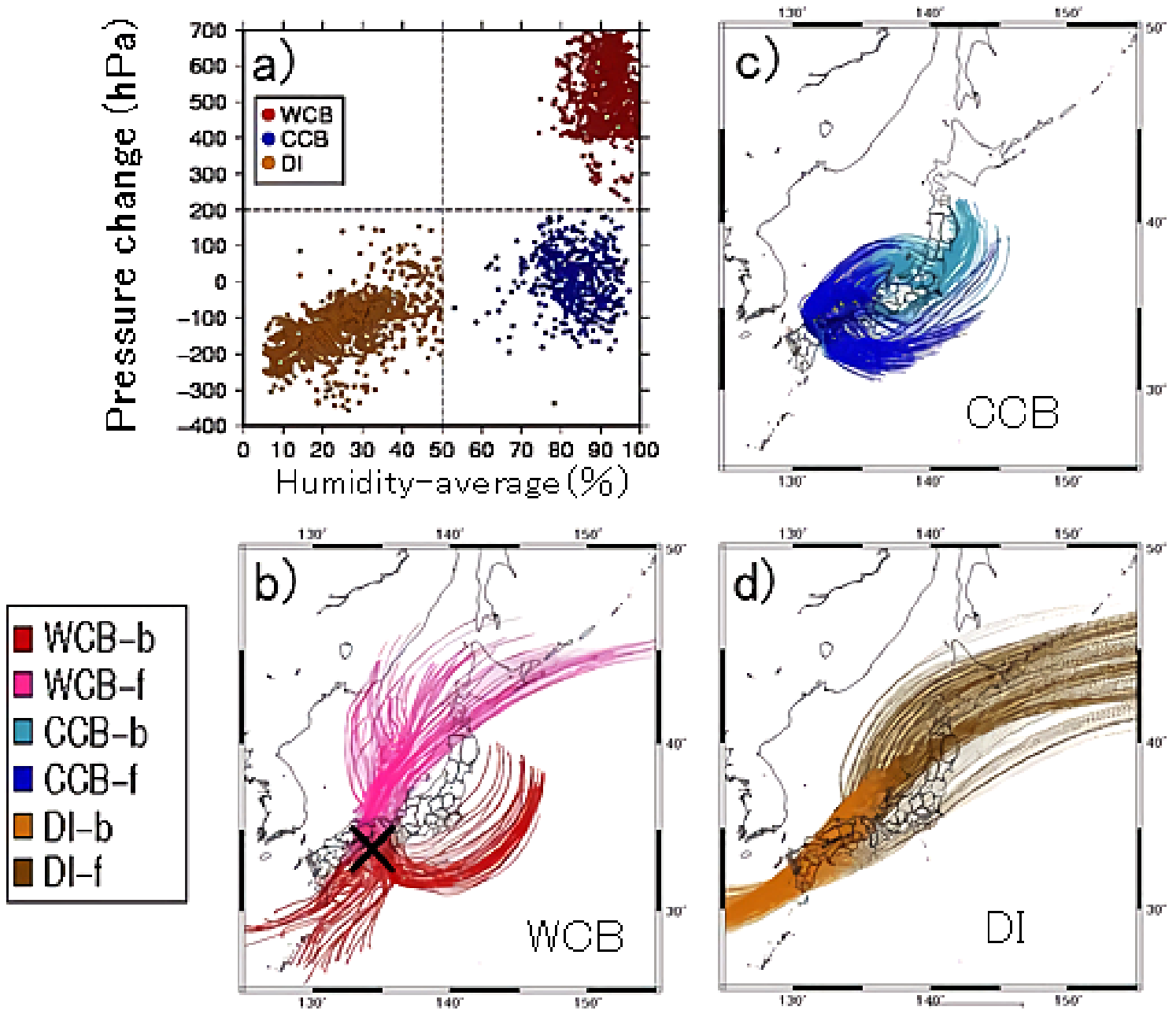

Fig. 2. a) Distribution of the WCB (red dots), CCB (blue dots), and DI (ocher dots) as functions of average humidity and pressure change (end minus start) during parcel travel for $48 \mathrm{~h}$ for a case on March 21-22. Routes of back (b) and forward (f) trajectories in different colors for b) WCB, c) CCB, and d) DI are shown with a center of low pressure $(\times)$.

given in Section 4.

\section{Effects of cyclone structure on the variabilities of point-measured precipitation}

The temporal change in the hourly precipitation during the passage of a cyclone was analyzed relating to the dominant conveyor belts over the observation point. The target is the first-ranked heavy precipitation event (December 10-11, 2015) (case $\alpha$ ). A cyclone moving northeastward over the main island with a bent warm front was analyzed in the morning surface weather chart on December 11 (Fig. 3a) with DI stretching from the Yellow Sea over western Japan into central Japan (Fig. 3b). Cloud distribution indi- cates precipitation areas $\mathrm{A}-\mathrm{C}$, explained in Section 2.3, shown as solid circles. The cyclone was blocked by a high-pressure system of $1030 \mathrm{hPa}$ at the center ahead and moved slowly, rather than developing explosively, and then it occluded during the night (figure omitted). Precipitation areas moved over most of the islands, especially more than $125 \mathrm{~mm}$ TAP was provided along the Pacific coasts of western Japan (Fig. $3 c)$. This is a good case for diagnosing how the hourly precipitation rate changed according to the passage of conveyor belts with cyclone movement.

First, the Sumoto Observatory (marked X in Fig. 3c and by a black dot in Fig. 5) located in the flat inland without high mountains was chosen. Continuous pre- 
a)

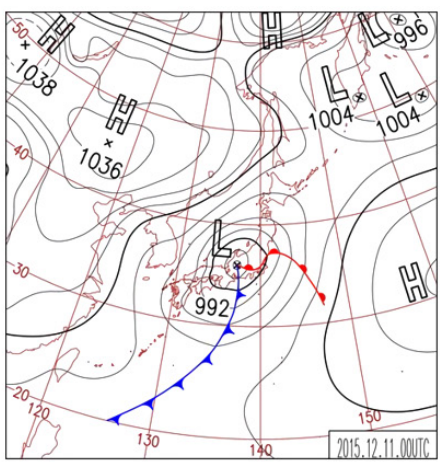

b)

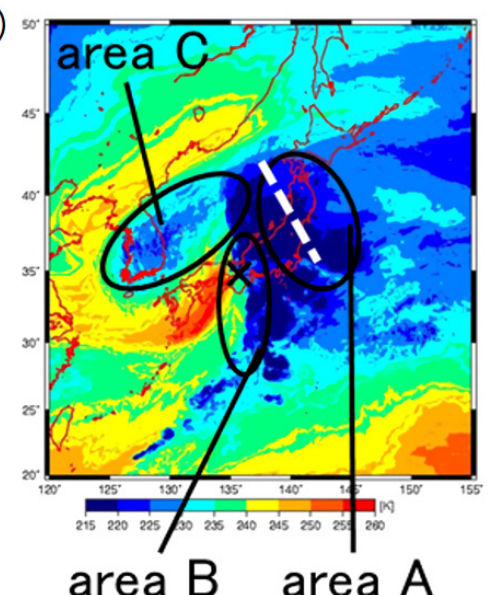

c)

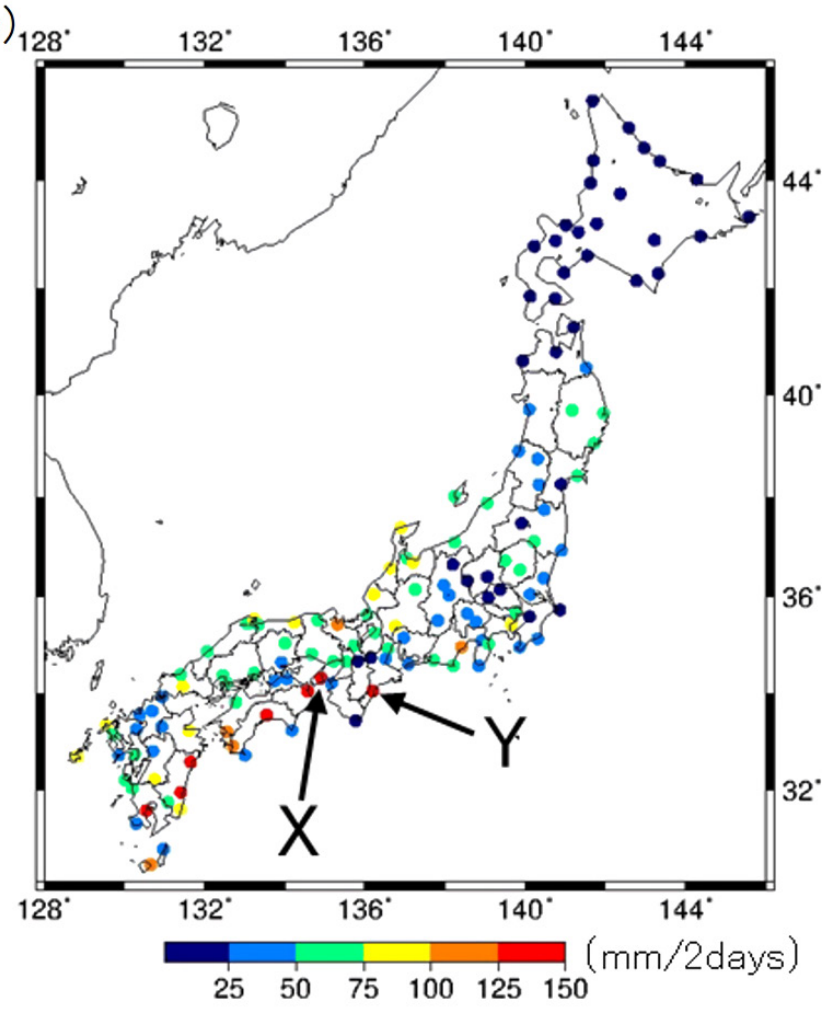

Fig. 3. a) JMA surface weather chart, b) satellite image of water vapor channel at 9 JST on December 11, 2015, and c) two days accumulated precipitation on December 10-11 (case $\alpha$ ). A-C corresponds to the precipitation areas categorized in Section 2.3. A white dashed bar indicates the passage of DPR observation. X and Y indicate the location of Sumoto and Owase, respectively.

cipitation of $12 \mathrm{~h}$ over midnight provided a TAP of 243 $\mathrm{mm}$. Temporal changes in hourly precipitation in Fig. 4a show that precipitation started in the evening on December 10, increased (T1), reached over $20 \mathrm{~mm} \mathrm{~h}^{-1}$ in the night, and remained for several hours (T2). In the early morning, 5 JST local time, heavy precipitation of over $50 \mathrm{~mm} \mathrm{~h}^{-1}$ was recorded (T3), and the rate suddenly reduced, and precipitation stopped after 7 JST (T4). JMA radar images showed that T1 was initiated by isolated precipitation areas formed over the Kii Peninsula mountains ahead of the main cyclone system under a weak surface pressure gradient condition (Fig. 5a, C1). In the T2 period, wideranging heavy precipitation areas east of the cyclone center spread over Sumoto (Fig. 5c, C2). Simultaneously, more areas of heavy precipitation stretched along the south-facing slopes of the mountains on Shikoku Island and the Kii Peninsula (C3), indicating orographic enhancement (Fig. 5d). Besides, heavy precipitation bands and precipitation-free areas were mixed when the cyclone center approached (Fig. 5e), and extreme heavy precipitation during T3 was caused by one of the band-shaped precipitation zones stretching southwest-northeast (Fig. 5f, C4).

Next, Fig. 4b shows temporal changes of the dominant conveyor belts identified using trajectory analysis over Sumoto, with the surface wind, CAPE, and VIWVD analyzed in ERA5 data (Fig. 4c). The trajectory analysis starts from 18 pressure levels of 300-950 hPa of an ERA5 data column at 16 JST on December 10 to 9 JST on December 11. During T1, the WCB prevailed less than $40 \%$ of the time with a small number of CCBs with weak surface wind conditions; however, the WCB percentage suddenly increased to over $70 \%$ after the start of heavy precipitation (T2) when strong southeasterly winds prevailed with changing direction from the south. Therefore, the WCB intrusion ahead of the cyclone center strongly 

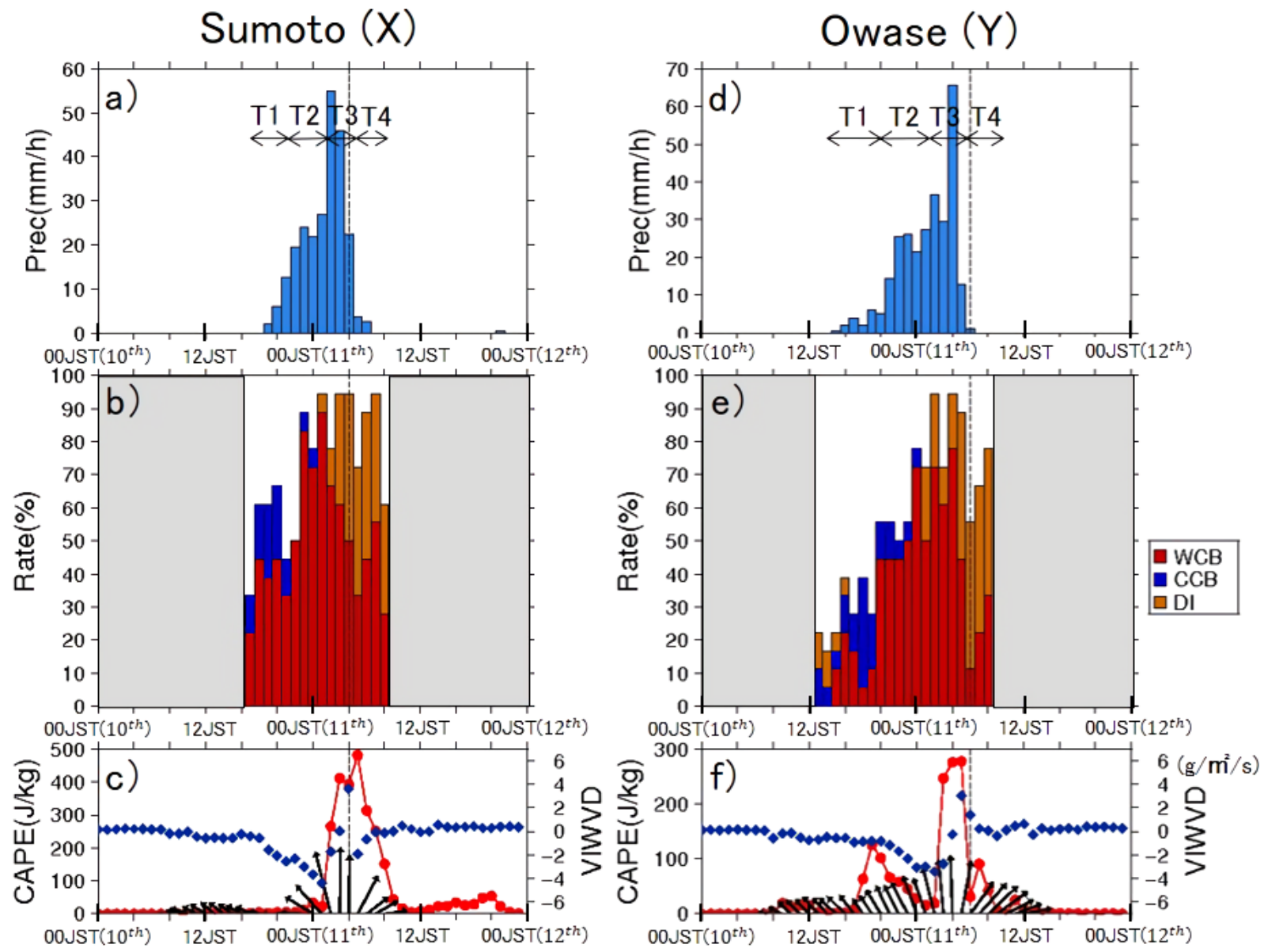

Fig. 4. Temporal change in hourly precipitation (a, d), percentage of trajectories with three categories (b, e) and CAPE (red line), surface wind vector (black arrow), and VIWVD (blue line) (c, f) at Sumoto (left) and Owase (right). The time sequence starts at 0:00 JST on December 10, 2015. Vertical dashed lines indicate the time at which the cyclone center was closest to each station. Time slots without trajectory analysis in b) and e) are shaded.

contributed to increased precipitation amounts. With 3-h time lags, DI started to prevail as CAPE increased when the extreme precipitation rate was recorded (T3), and the WCB percentage gradually reduced without the CCB. According to the radio-sounding data at 9 JST on November 11 at Shionomisaki station $80 \mathrm{~km}$ southwest of Owase, the DI reached a $700 \mathrm{hPa}$ level without upper cold airmass (figure omitted) and a profile of equivalent potential temperature showed a convective instability condition below $600 \mathrm{hPa}$. The CAPE diagnosed in objective analysis data might not directly indicate mesoscale convective instability; however, it is used as the CAPE closure for convective parameterization in large-scale models (Bechtold 2014) and corresponds to observed precipitation increases. The direction of the stretching band-shaped precipitation zone in the radar image (Fig. 5f) corresponded to the DI airstream. Therefore, we attributed that the vertical humidity gradient strongly affected the extremely heavy precipitation to increase convective instability and CAPE by the DI over the WCB, forming band-shaped mesoscale convective clouds with precipitation-free areas in the cyclone system's maturing stage.

The same analysis was done over the Owase Station (marked Y) on the southeastern coast of the Kii Peninsula, where ascending effects by mountains behind should increase the amount of precipitation during the passage of synoptic disturbances (Takeda et al. 1976). Precipitation continued for 16 h (Fig. 4d) and $280 \mathrm{~mm}$ TAP was recorded. The pattern of change in the hourly precipitation is similar; even the orographic 
a)

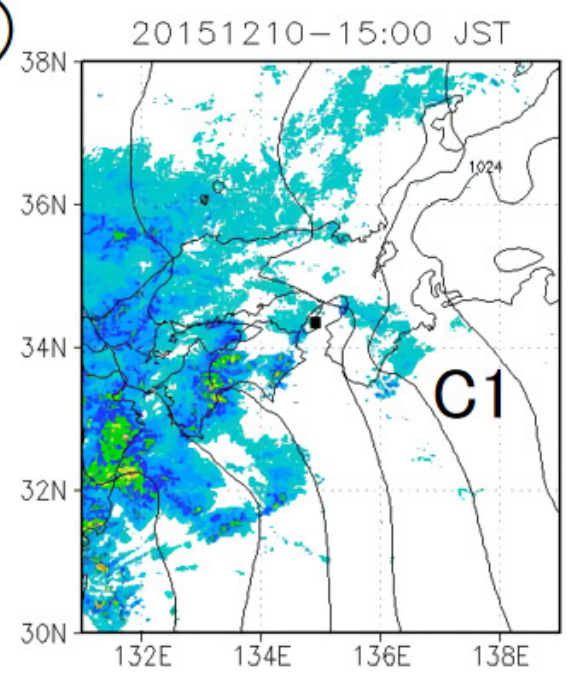

b)

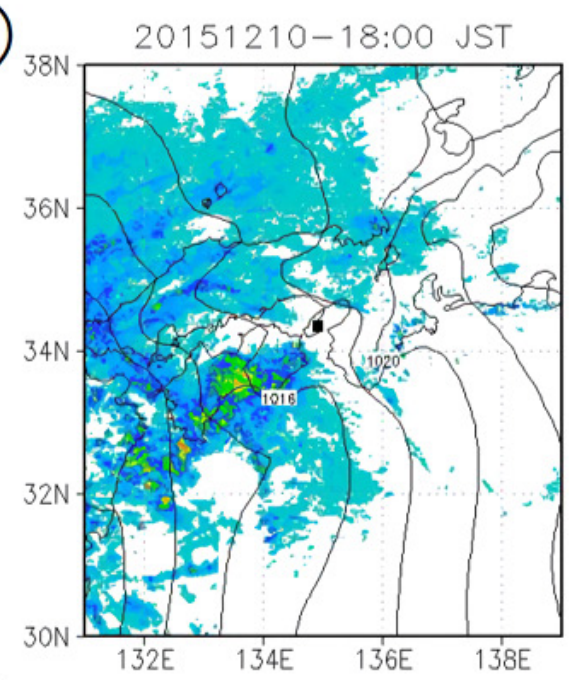

c)

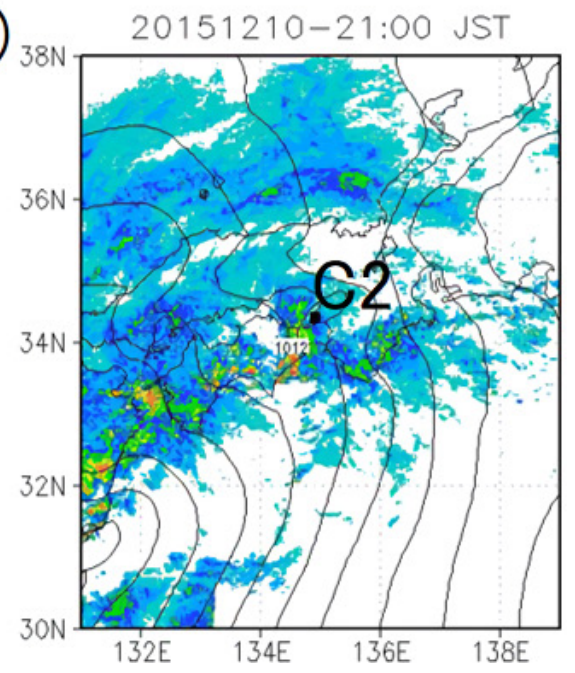

d)

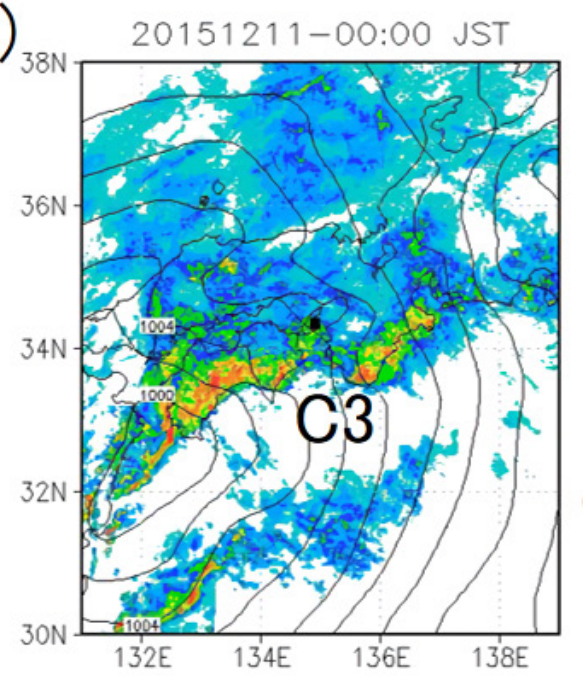

$(\mathrm{mm} / \mathrm{h})$

e)

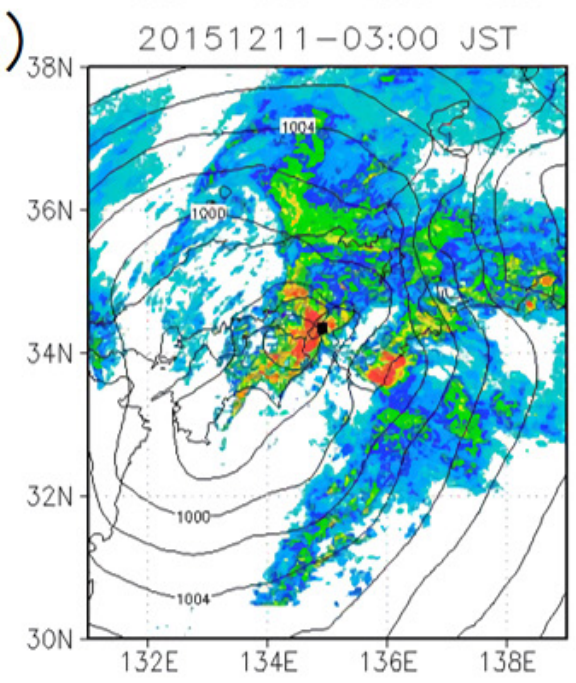

f)

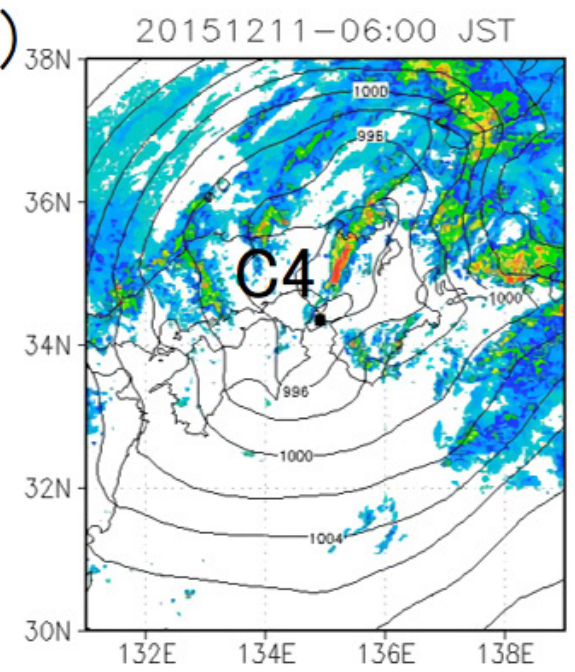

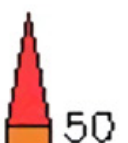

30

20

10

6

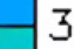

3

Fig. 5. JMA composite weather radar echoes images with 3-h intervals in the case of the December 10-11 precipitation event. A black circle indicates the location of the Sumoto Observatory. 
effects were expected, except that the precipitation started earlier than that at Sumoto and the Owase location was farther east with a longer T1 period. The conveyor belt percentages over Owase also showed similar stepwise changes (Fig. 4e), such that the increase in the WCB and DI percentages corresponds to the hourly precipitation changes as T2 and T3. During the T1 period, surface winds from the southeast dominated with increased CAPE, indicating the precursor initiation of orographic precipitation (Fig. 4f). CAPE decreased temporarily, suppressed before the DI that might be affected by precipitation. Consequently, case $\alpha$ shows that the cyclone structure composed of airstreams primarily affected the hourly precipitation changes contributing to the heavy winter precipitation events along the southwest coasts of Japan. Orographic enhancement of precipitation amounts also co-existed; however, the intrusion of a dry air mass in the mature cyclone stage induced an extreme increase in the precipitation rate.

In the following section, we nominated SCCs with similar cloud and frontal patterns in Table 1, and three matching cases with DPR observation were analyzed that represent the examination of the vertical structure of precipitation systems in areas $\mathrm{A}-\mathrm{C}$, respectively.

\section{Structures of mesoscale precipitation systems embedded in the cyclone}

\subsection{Continuous precipitation associated with stratiform clouds ahead of the cyclone center}

A three-dimensional precipitation system ahead of the cyclone center (area A) was diagnosed using DPR data regarding airstreams embedded in the cyclone. We focused on case $\alpha$, as introduced in the previous section. The DPR passed over the northern part of the main island (white dashed line in Fig. 3b) at 5 JST and captured precipitation in a zonal area of $245 \mathrm{~km}$ wide. The precipitation type, as defined in the DPR products (Le and Chandrasekar 2013) was predominantly classified as stagnant stratiform clouds (Fig. 6a) with flat distributed echo-top heights at a 2-6 km level (Fig. $6 \mathrm{~b})$. Surface precipitation areas were also distributed widely and continuously (Fig. 6c), and a stronger precipitation rate (more than $2 \mathrm{~mm} \mathrm{~h}^{-1}$ ) extending longitudinally corresponds to higher echo-top height areas (D1, D3 in Fig. 6b). Figures 6d and 6e shows the vertical cross-sections of the DPR echo along twodashed lines (Fig. 6c), one at the southwestern periphery and the other at the center of the observation pass. A cross-section along the former pass shows that the echoes were intensified below the $3 \mathrm{~km}$ level. Temperature profile data at 9 am by radio-sounding observation at Akita (marked in Fig. 6a) indicated that $0^{\circ} \mathrm{C}$ was located at $2.5 \mathrm{~km}$ above sea level (a.s.l.); therefore, the intensification was because of the bright band $(\mathrm{BB})$. The stratiform precipitation is shallower in the northern cross-section with more prominent $\mathrm{BB}$ (Fig. 6e). DPR captured several cells, and intensified cells, such as in D1, reached echo-tops of more than 6 $\mathrm{km}$ a.s.l. Although enhanced low-level echoes existed over the coastal areas, they were not because of a local coastal front without surface wind shear. According to the Nonhydrostatic Model high-resolution simulation, in a case of heavy winter snow by an extratropical cyclone in 2014 by Araki and Murakami (2015), the formation of snow particles at a $6-8 \mathrm{~km}$ level was also simulated because of ascending ahead of the surface warm front that differed from the feeding effects over mountains below $1 \mathrm{~km}$. Here, the low-level enhancement of the precipitation echo over the mountain was found, such as D3 over mountains, indicating that orographic ascending or seeder-feeder effects might be partially functioning. However, we attributed the formation of deep and wide-ranged stratiform precipitation to the ascending WCB at higher elevations.

Trajectory analysis was performed from the ERA5 data grids originating on the cross-sections of DPR observation in Figs. 6d and 6e, as explained in Section 2.4. ERA5 grids categorized in the airstreams were plotted as different colors/marks with the horizontal wind vector on the cross-sections of the DPR echoes. In the western cross-section (Fig. 6d), WCBs were identified in two areas. One is a dense group below 3 $\mathrm{km}$ in the southeastern portion coming from the south to the southwest rising over the CCB and intruding from the south at the bottom. The potential temperature of the WCB and CCB were different (CCB was $4-8 \mathrm{~K}$ colder). The other is the scattered group in the upper level up to $9 \mathrm{~km}$ coming from the southwest. A few DIs were analyzed at the upper-north level over the SJ, but they were not dominant. A similar structure was shown along the center cross-section (Fig. 6e), except that the CCB at the bottom was shallow.

We focused on heavy precipitation cells over D1 composed of WCB groups at two levels with CCBs at the bottom. Figure 7 shows the horizontal/vertical movement of parcels chased from a column (marked by a dashed line in Fig. 6d). Parcels of the CCB intruded from the Pacific with a clock-wise rotation when approaching the cyclone, remained over the island and returned eastward when passing the cyclone northeast of the Tohoku area (Fig. 7a), maintaining heights below $2 \mathrm{~km}$ (Fig. 7c). A low-level WCB (WCB1), identified in the southern portion in Figs. 6d 


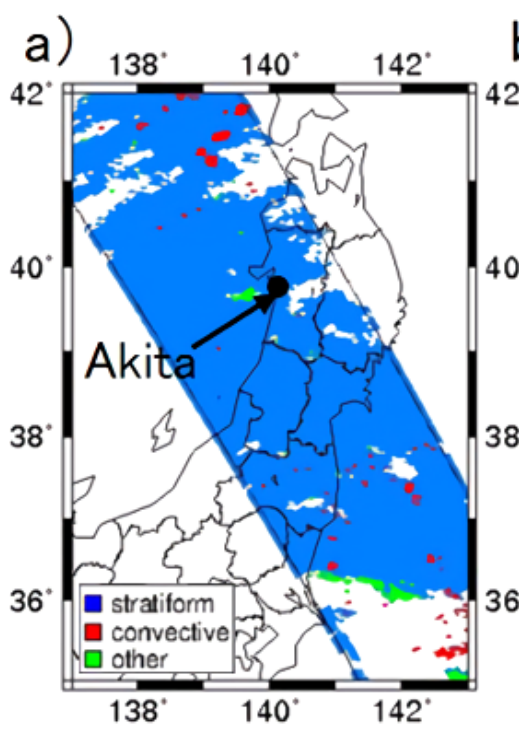

b)

$138^{\circ}$ $140^{\circ}$ 142

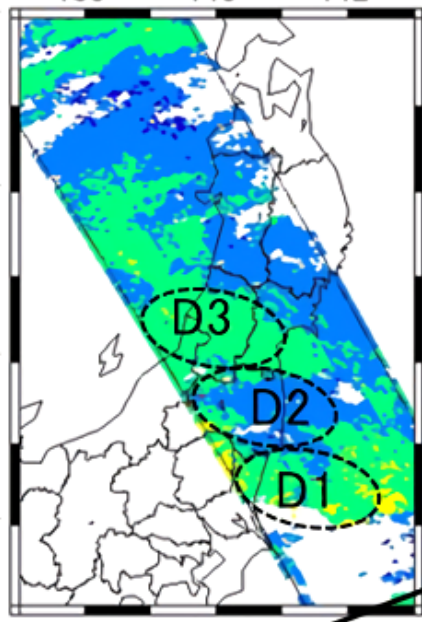

$138^{\circ}$ c)

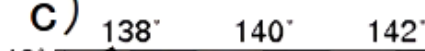

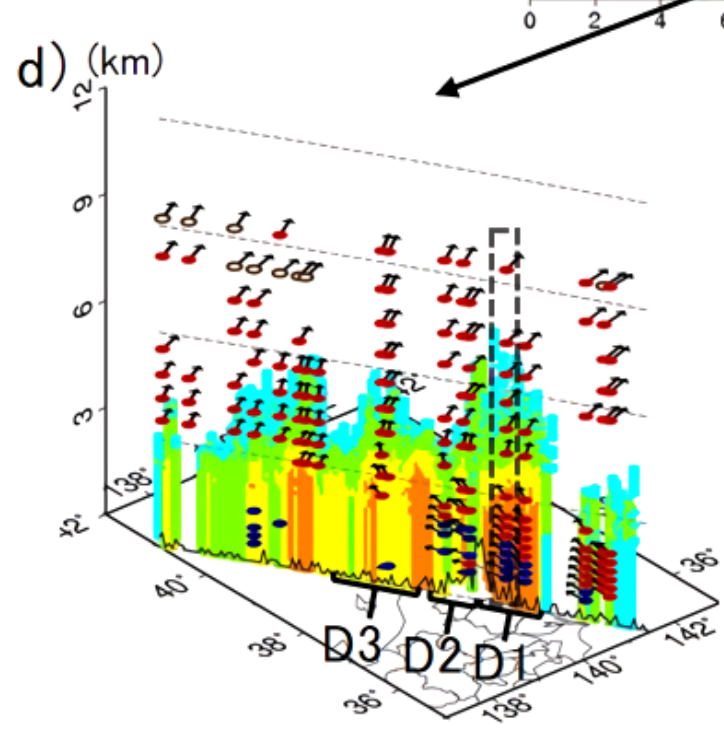

e)
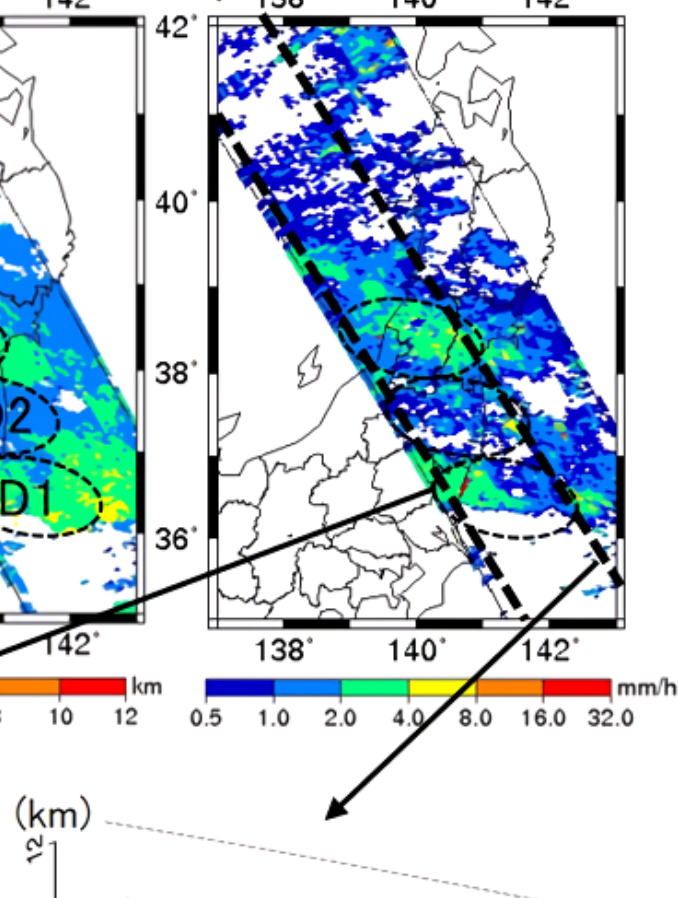

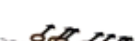
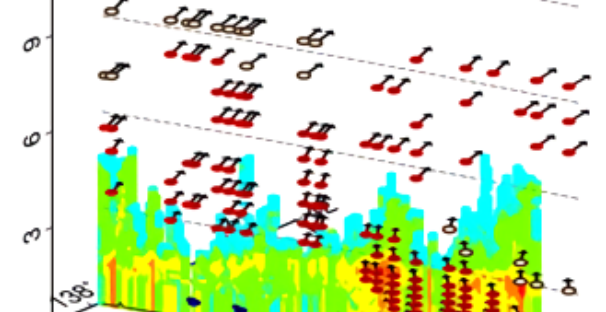

si

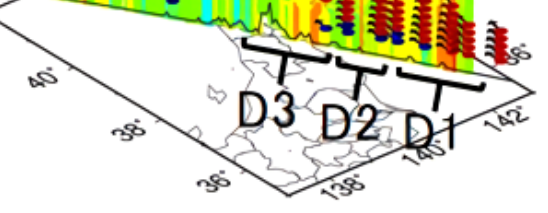

ODI

Fig. 6. Distribution of a) precipitation type, b) echo-top height, and c) precipitation intensity at the surface for case $\alpha$ (5 JST on December 11, 2015), produced by GPM-DPR observation. Vertical cross-section of the DPR precipitation echo intensity along the southwest (d) and central (e) transect, illustrated in (c). Marks with different-colored arrows on the cross-sections correspond to the airstream with horizontal air parcels.

and $6 \mathrm{e}$, chased a route in front of the $\mathrm{CCB}$ from the east (red line in Fig. 7a). In the vertical section (Fig. 7c), parcels first descended from $5 \mathrm{~km}$ to $2 \mathrm{~km}$ along the periphery of a high-pressure system ahead of the cyclone, ascended after passing the original section (dashed line), and moved northward at elevations above $6 \mathrm{~km}$ high over a $1000 \mathrm{~km}$. The synoptic-scale ascending motion in area $\mathrm{A}$ is speculated to dominate WCB1.

However, upper WCBs (WCB2) in Figs. 6d and 6e followed a route along the archipelago from the southwest (green lines in Fig. 7a), maintaining a height at 

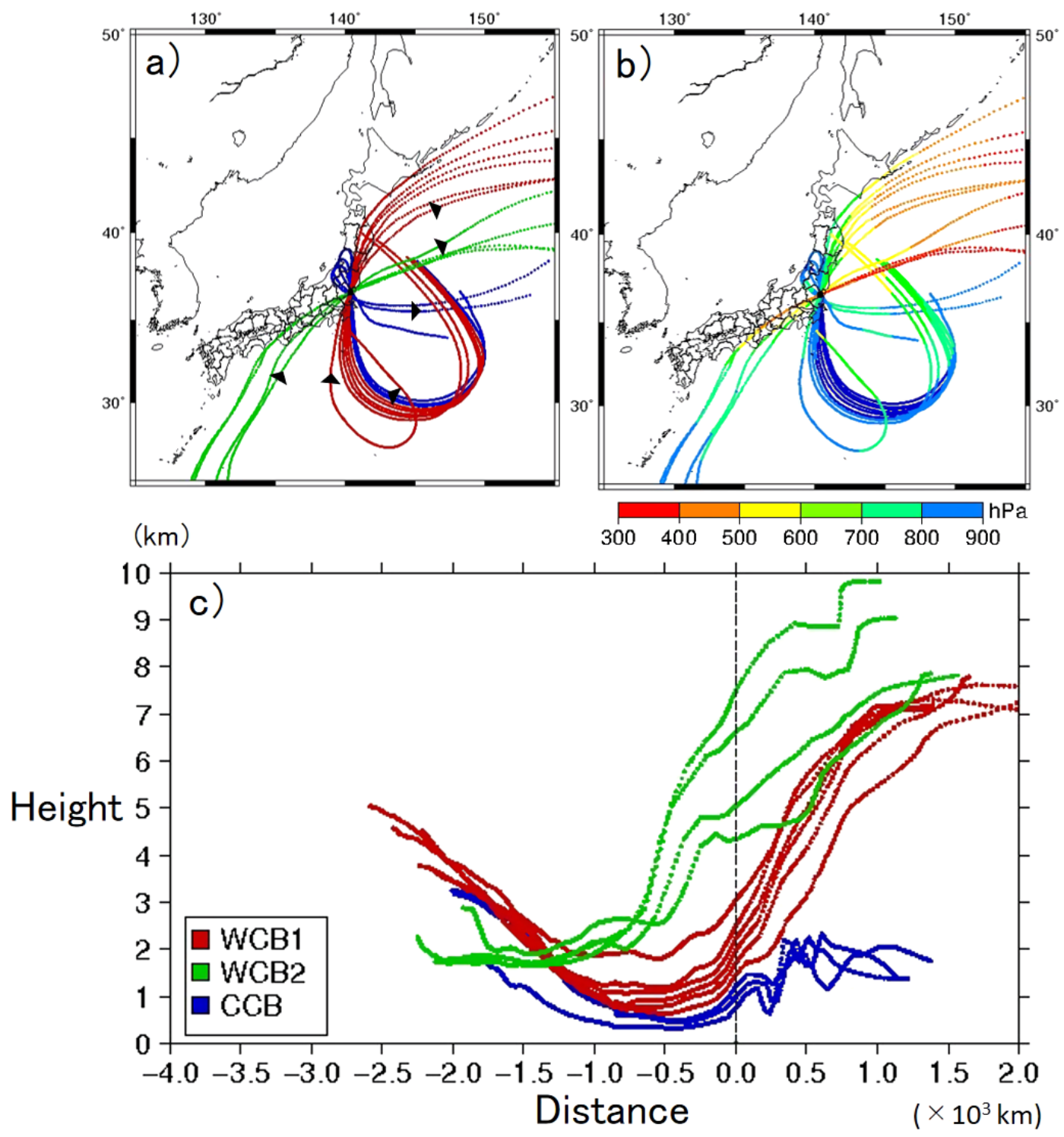

Fig. 7. a) Hodograph of air parcels chased from a column indicated by a dashed box in Fig. 6c by back and forward trajectory analysis (the colors indicate the category of airstream, and arrows demonstrate directions), b) altitude change of the air parcel along the trajectory (the colors indicate the height as a function of pressure), and c) vertical cross-section of trajectory height level as a function of distance $(\times 1000 \mathrm{~km})$ from the start points, as indicated by a dashed line.

$\sim 2 \mathrm{~km}$. Note that the altitude increased to $\sim 500 \mathrm{~km}$ before the original section (green lines in Fig. 7c). Namely, this ascending did not occur in area A, as will be discussed in the next section. The height of their routes was diverse above $4 \mathrm{~km}$, recognized as upperscattered WCBs in Figs. 6d and 6e, and flowed northeastward following the cyclone center's movement. This indicated that two distinct WCBs affected the deep stratiform clouds identified by DPR observation. One is the air mass coming from the south and stranded over the $\mathrm{CCB}$, contributing to the formation of deeper stratiform echoes in the southern border as a common surface warm front. The other is the upper air mass intruded from the southwest that supplies rich water vapor to the stratiform cloud areas. Grim et al. (2007) also demonstrated a warm moist airstream aloft 
a)

b)
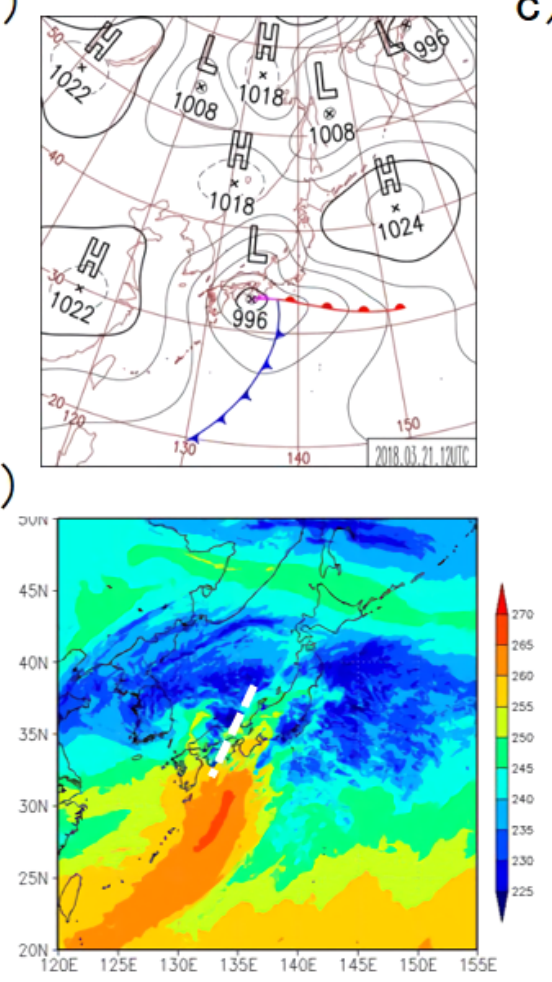

c)

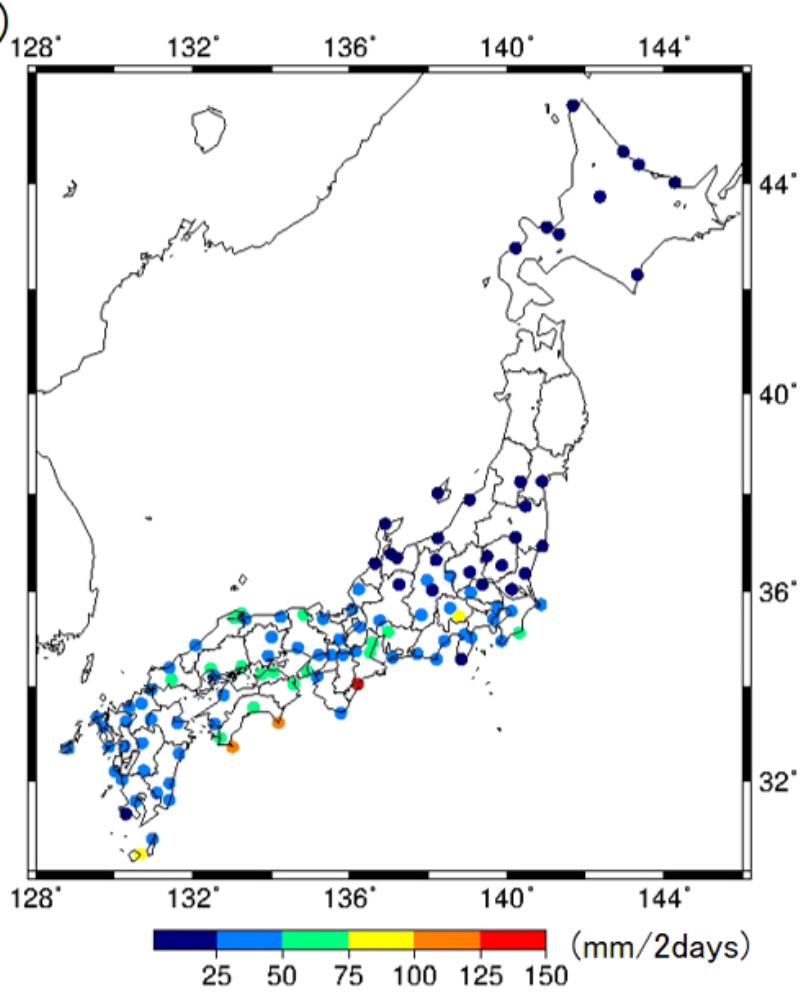

Fig. 8. The same as Fig. 3, except for case $\beta$, such as a) weather chart at 12 JST on March 21, 2018, b) satellite image at $17 \mathrm{JST}$, and c) during March 21-22.

categorized as the WCB, not by a surface-level cold front but by a trowal structure in the winter continental cyclone. Linkage to this study is discussed later.

\subsection{Heavy precipitation by convective clouds with the upper dry intrusion}

This section explains the precipitation system around the cyclone center (area B) using the 9th event on March 20-21, 2018 (case $\beta$ ) when the DPR could pass over the target phenomenon. Fig. 8a shows an SCC with an occluding front at 21 JST on March 21. In the evening, the DI extended from the southwest toward the cyclone center when the DPR at 17 JST observed the precipitation system along a southwestnortheast transect over western Japan (Fig. 8b). The cyclone provided $\sim 50 \mathrm{~mm}$ TDP in western and central Japan, and heavy precipitation of more than $100 \mathrm{~mm}$ TAP occurred along the Pacific coasts of Shikoku and the Kii Peninsula (Fig. 8c). Figure 9 shows features of the precipitation system in the DPR observation areas as the same expression of Fig. 6. Distinguished convective precipitation prevailed over Shikoku Island (G1) and along the SJ coast with zonal bands (G3) accompanied by wedge-shaped precipitation-free areas in the southeast. Increased surface-level precipitation amounts correspond to individual convective cells with an echo-top height of $\sim 8 \mathrm{~km}$, which is not extremely high (Fig. 9b). Besides, stratiform precipitation extends in the north over the SJ with a flat echotop distribution below $6 \mathrm{~km}$.

According to a DPR vertical section of echo intensity along a northwestern section (Fig. 9d), multiple convective cells in the south (G1) are parts of the convective zone stretching southeastward (Fig. 9a) corresponding to the head of the DI in the water vapor channel of a geostationary satellite image (Fig. 8b). Radio-sounding data at 21 JST at Shionomisaki station indicated that the DI reached $950-850 \mathrm{hPa}$ with a temperature inversion layer at the bottom 950 $\mathrm{hPa}$, corresponding to the $\mathrm{CCB}$. In the north, the echo pattern was different, showing a rather flat distribution with a BB at $\sim 2 \mathrm{~km}$ (radio-sounding data at Wajima at $21 \mathrm{JST}$ showed that a $0^{\circ} \mathrm{C}$ level existed at $\sim 3 \mathrm{~km}$ ), confirming stratiform precipitation. Airstreams detected using trajectory analysis show that convective areas (G1) are composed of CCB from the east at the lowest 

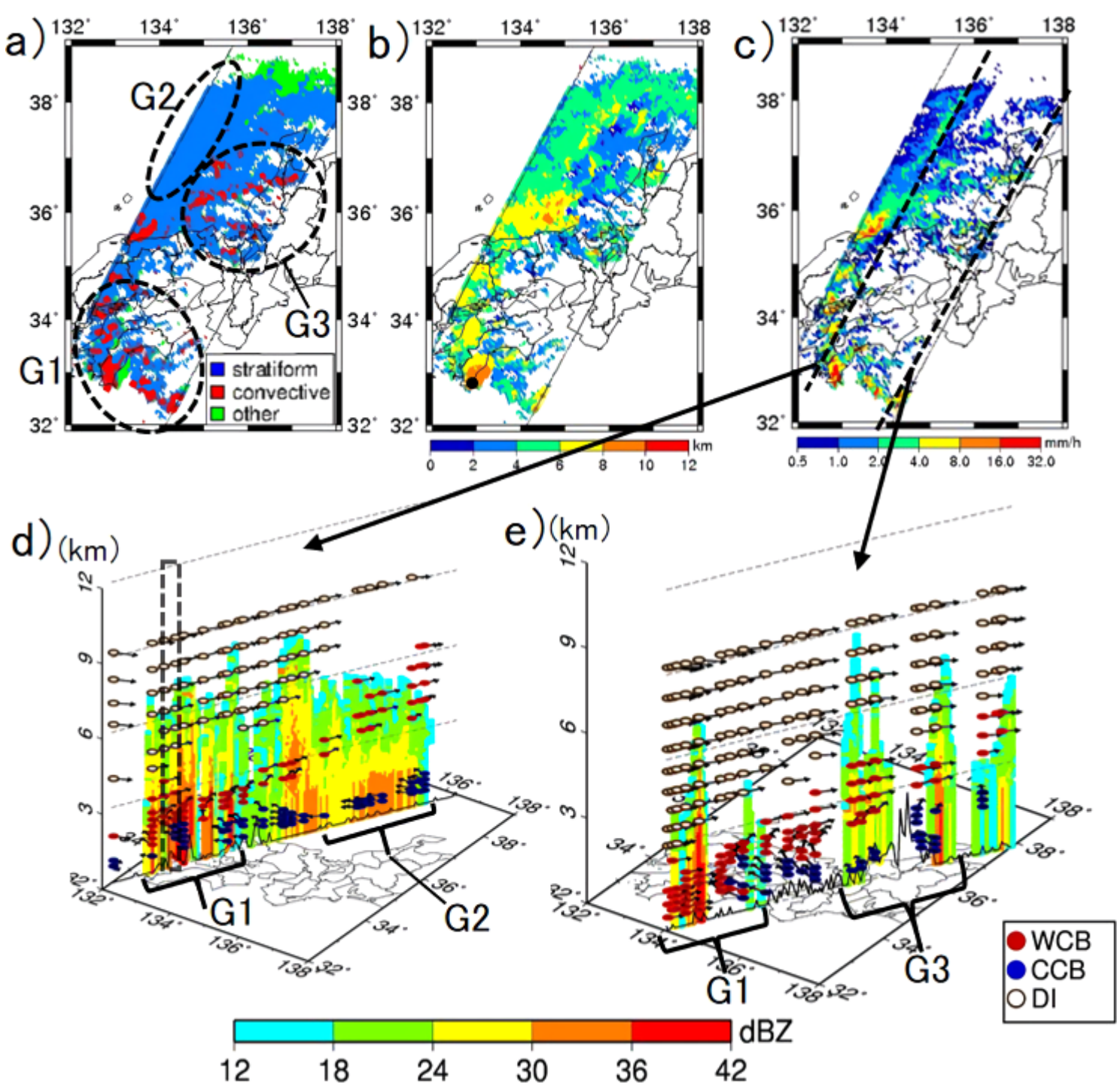

Fig. 9. The same as Fig. 6, except for case $\beta$ at 17 JST on March 21, 2018.

level, the WCB from the south at $\sim 2 \mathrm{~km}$ level, and DI from the southwest over the WCB. Mid-level DI (3-5 $\mathrm{km}$ a.s.l.) vanished inland because of deformation by northern convective cells. Similar enhancements of convective clouds with the DI over the WCB were observed along a southeastern transect at the southern borders of precipitation areas (Fig. 9e). We attributed this feature to the occurrence of the upper front, as modeled by Browning and Monk (1982). Compared to their classical model, DPR observation with water vapor imaging indicated that the upper front was composed of more zonally distributed convective cells orthogonal to the DI with a shallow WCB.
However, stratiform echo areas (G2) were composed of a lower bottom CCB from the east with an upper disconnected WCB from the south to the southwest over $3 \mathrm{~km}$ without the DI. The CCB intruded anticlockwise north of the cyclone center along the occluding front, where the WCB overlapped indirectly, which was like the structure observed in the northern parts in the first-ranked case (Fig. 6d). Namely, this cyclone was also composed of two precipitation types, such as the convective precipitation dominant area (B) and stratiform precipitation dominant area (A), where the DPR crossed over those two areas.

Figure 10 shows the routes of an air parcel de- 

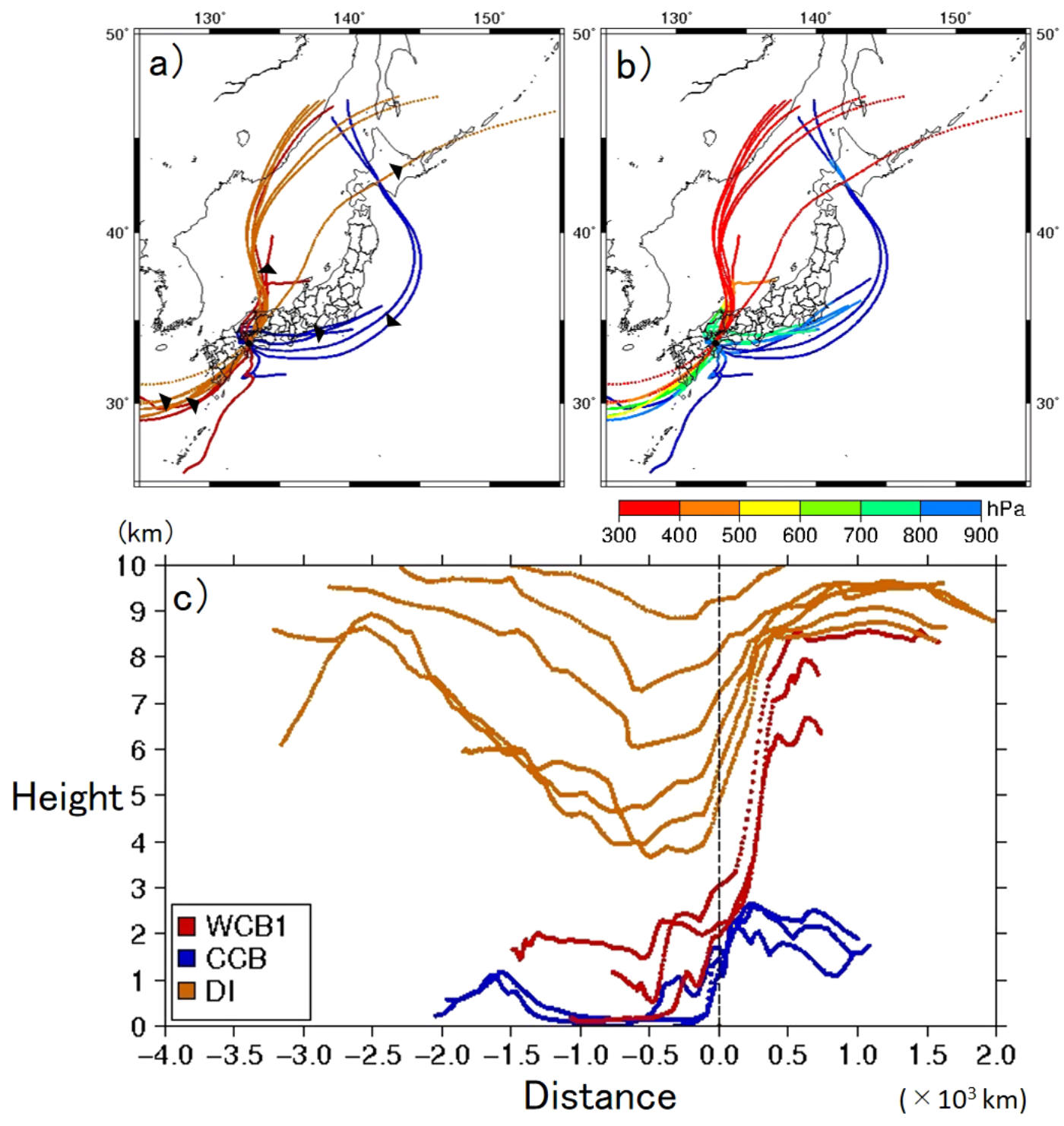

Fig. 10. The same as Fig. 7, except for case $\beta$ starting from a column indicated by a dashed box in Fig. 9 over G1.

pending on the airstreams originating from a dashed column in the G1 area. The CCB (blue lines in Fig. 10a) intruded from the east and returned eastward or southward according to the cyclone movement below $3 \mathrm{~km}$ a.s.l. Besides, only one principal route for the WCB (red lines) intruded from the southwest northward, with evident height increases from below 2 $\mathrm{km}$ to more than $6 \mathrm{~km}$ a.s.l. after passing area B. The DI also pursues a similar route, descending from the upper level more than $8 \mathrm{~km}$ to as low as $4 \mathrm{~km}$ above $50-100 \mathrm{~km}$ before the target area, then ascending again over the WCB to more than $8 \mathrm{~km}$. The abrupt ascending of the WCB and DI implied convective activities in the G1 area. Another critical perspective is the routes of the WCB after ascending. High-level WCBs moved north-northeast and entered the stratiform precipitation areas ahead of the cyclone, which is consistent with the behavior of WCB2 diagnosed in case $\alpha$ (Fig. 7), which ascended in advance to stratiform area A. This analysis indicates that deep convective clouds with the upper front in the occluding stage are also critical in branching the WCB to intrude a warm moist air mass over the stagnant stratiform areas in front of a cyclone center. 
The CAPE distribution analyzed in the ERA5 (Fig. 11a) shows a maximum zone stretching southeastward, corresponding to the G1 area in the DPR image and ahead of DI in the water vapor channel. The PV distribution at $300 \mathrm{hPa}$ (Fig. 11b) shows a maximum zone over northern Kyushu stretching westward allocated west of the DI (Fig. 8b) and low-level positive PV distribution was deformed zonally accompanied by negative PV in the north (Fig. 11c), confirming the theory that the upper high PV area supplied the DI (Browning 1997). In the ERA5 data, another weak CAPE maxima exist where the lined convective cells were identified (G3 in Figs. 9a, 11a). According to the trajectory analysis chased from a dashed column over G3 in Fig. 9e, the DI also remained at an altitude of $5 \mathrm{~km}$ in the mid-troposphere. Therefore, the dry air mass descending over a wet WCB could enhance convective instability and produce a high CAPE that is favorable to initiate severe convective activities, as captured by DPR profiles around a cyclone center with an occluding stage. Broadly distributed convective precipitation areas extending over the SJ coasts provided a certain amount of precipitation (Fig. 8c), even as the cyclone center passed along the Pacific side, and the TAP increased to rank this case as one of the heavy precipitation events.

\section{Latent heating in the mid-troposphere with occluding process observed by DPR}

One characteristic of cloud formation with an occluding extratropical cyclone is the formation of stationary cloud-head areas that extend cloudy weather and precipitation periods behind the cyclone center. We selected an 11th event (March 10-11, 2019, case $\gamma$ ) when the DPR-observed the rear parts of the cyclone from the southwest to the northeast at 9 JST on March 11. The DI in the southeast intruded the cyclone with an occluding front moving northeastward, with the extension of the cloud-head over central Japan and the eastern SJ on March 11 (Figs. 12a, b). TAPs of more than $25 \mathrm{~mm}$ were produced in most main islands, except in Hokkaido. According to the DPR observation, precipitations were predominantly the stratiform type with flat echo-top heights below $6 \mathrm{~km}$ during the observation pass (Figs. 13a, b). A weak surface precipitation rate of $1-2 \mathrm{~mm} \mathrm{~h}^{-1}$ was widely distributed (Fig. 13c). A cross-section of the echo profile along a northwestern section (Fig. 13d) shows BBs at $\sim 2 \mathrm{~km}$ in the cloud-head area (I1) corresponding to a $0^{\circ} \mathrm{C}$ level observed by radio-sounding at 9 JST over Akita. The profile was almost unique, but some cloud-cell enhancements were observed with echo-top height

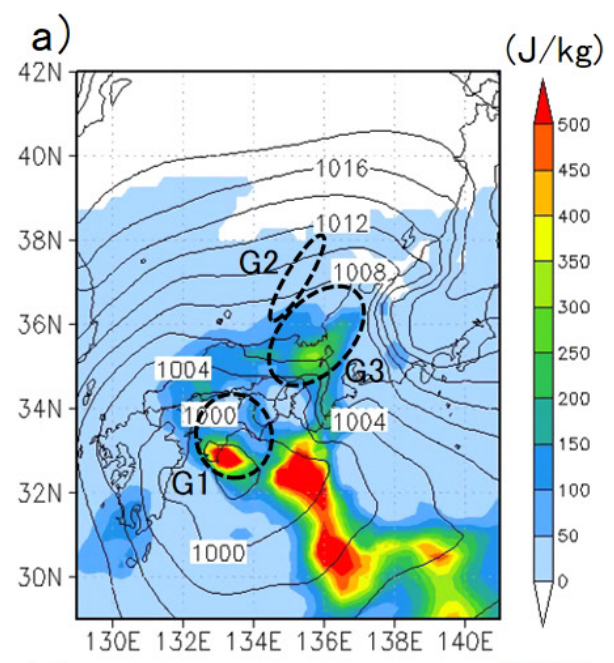

b)
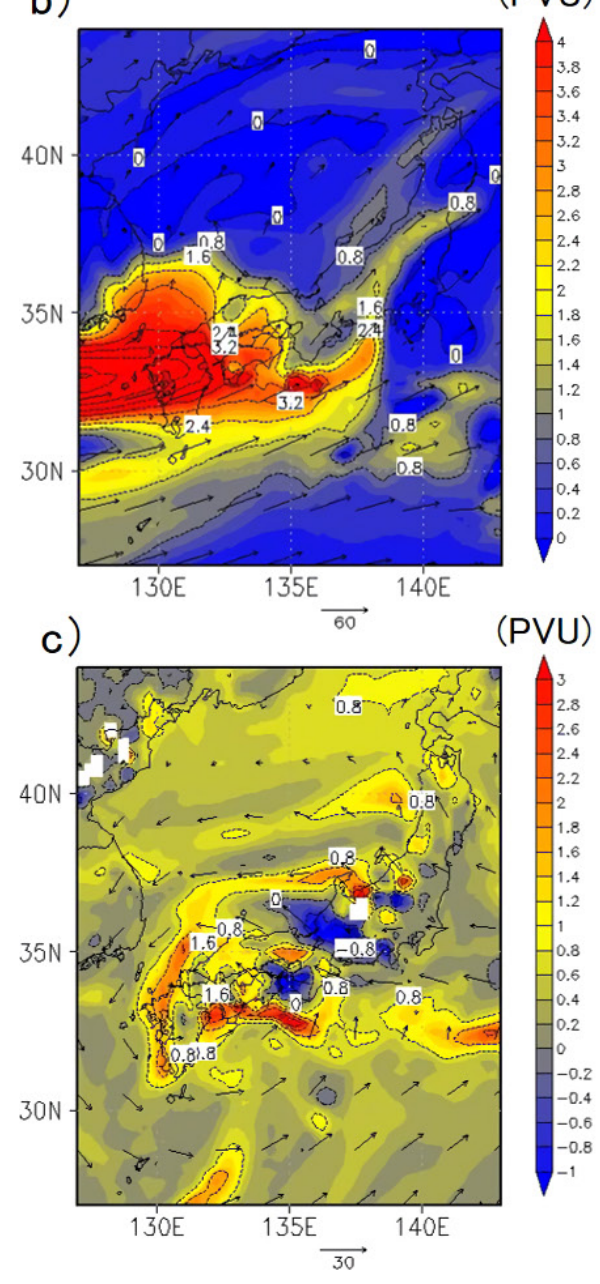

Fig. 11. Distribution of a) CAPE with sea-surface pressure level, b) $\mathrm{PV}$ distribution at $300 \mathrm{hPa}$, and c) the same for $850 \mathrm{hPa}$ at $17 \mathrm{JST}$ on March 21, 2018 by ERA5 data. 
a)

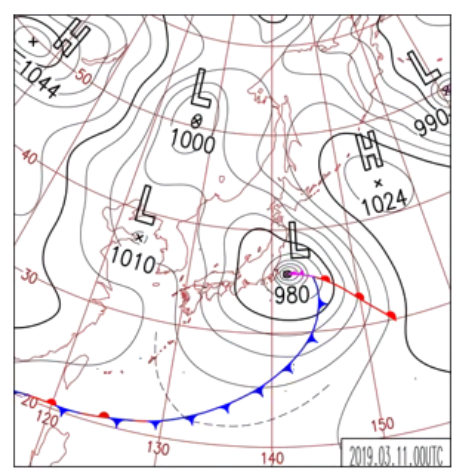

b)

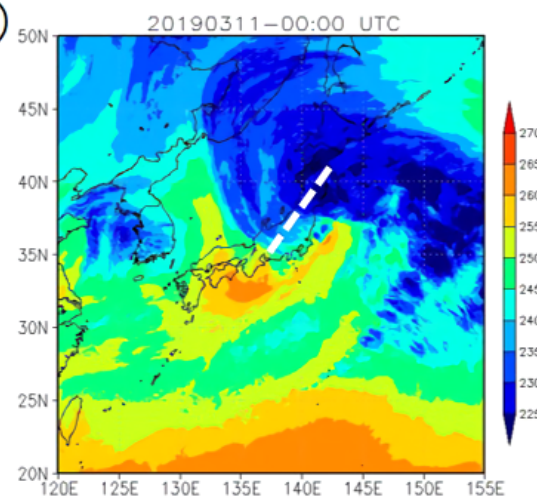

c)

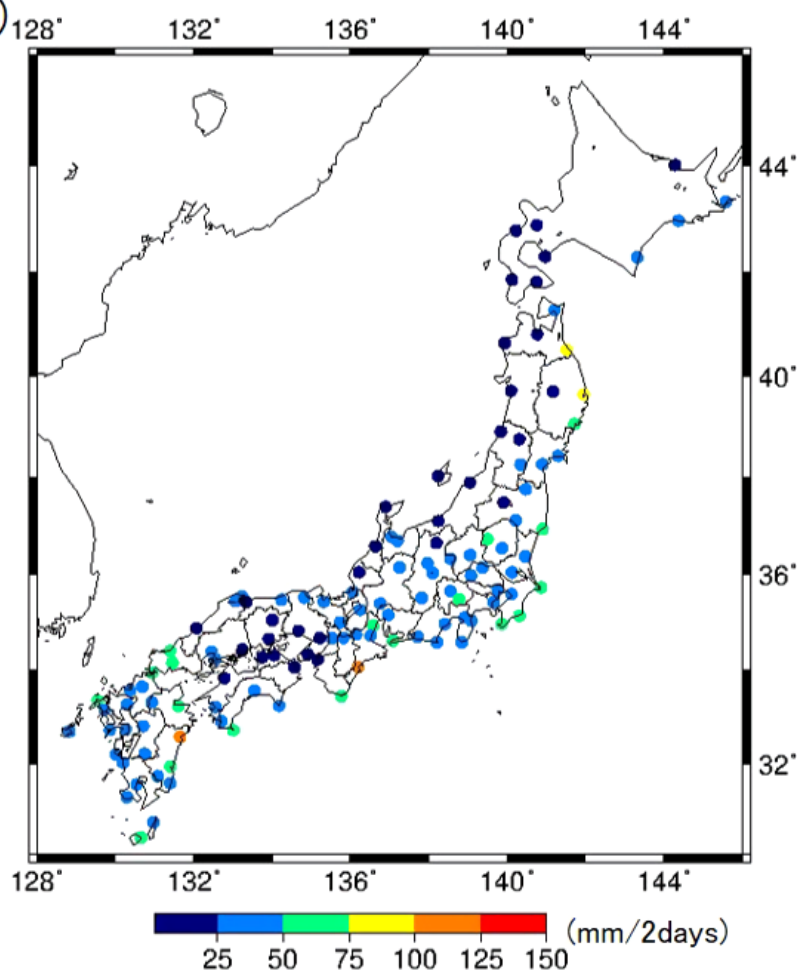

Fig. 12. The same as Fig. 3, except for case $\gamma$, such as a) weather chart at 9 JST on March 11, 2019, b) satellite image at 9 JST, and c) during March 10-11.

increased to $5 \mathrm{~km}$. In the northern parts, precipitation echoes were observed over the $3 \mathrm{~km}$ level without precipitation at the surface, where the precipitation type was categorized as other (green areas in Fig. 13a). Along the southeastern section (Fig. 13e), the echotop height was higher than $5 \mathrm{~km}$, but the BB level is almost the same as in the western profile, and stronger precipitation cells were observed in the northern parts (I2).

We focused on the southeastern precipitation profile (Fig. 13e), where thicker stratiform precipitations were attached to precipitation-free areas in the south. According to the trajectory analysis, the CCB intruded from the east at the bottom below $2 \mathrm{~km}$ in the central and northern areas in the cyclone, then it turned anticlockwise around $90-180^{\circ}$ to head eastward. WCBs were distributed in two distinct areas. One is below 4 $\mathrm{km}$ over the CCB from the southeast in the northern section (I2). This WCB had the same structure as case $\alpha$ (Figs. $6 \mathrm{~d}, \mathrm{e}$ ) ascending over the CCB in area A. The other is in the upper level with a gradual increase in elevation, 5-7 km in the south to over $6 \mathrm{~km}$ in the north, and they distributed over the precipitation pro- file. The structure is like that of the northern portion of area A, as introduced in Section 4.1, except that the average echo-top height over I1 was higher with CCBs at the bottom than that in the profiles of Figs. 6d and $6 \mathrm{e}$. In the south of the I1 area without precipitation echoes, thick DIs from the south are contiguous over westerly WCBs. The DIs are also captured in the WV channel of the satellite image (Fig. 12b). Namely, the WCBs from the west entered under the DIs anticlockwise behind the cyclonic center that might induce conversion over I1 to induce stratiform echoes. The sandwiched structure of upper warm moist airmass, identified as WCBs between DI at the upper south and $\mathrm{CCB}$ at the bottom, with precipitation generation from high-level clouds resembles the formation of a trowal-warm-front, as explained by Grim et al. (2007, Fig. 15). However, the upper WCB, in this case, was not bounded by the southerly DI because the main DI over the Pacific sides flew northeastward at 500-700 $\mathrm{hPa}$ levels.

Han et al. (2007) showed a frontogenesis pattern at the trowal level and the importance of latent heating and cooling processes to modify the transverse frontal 


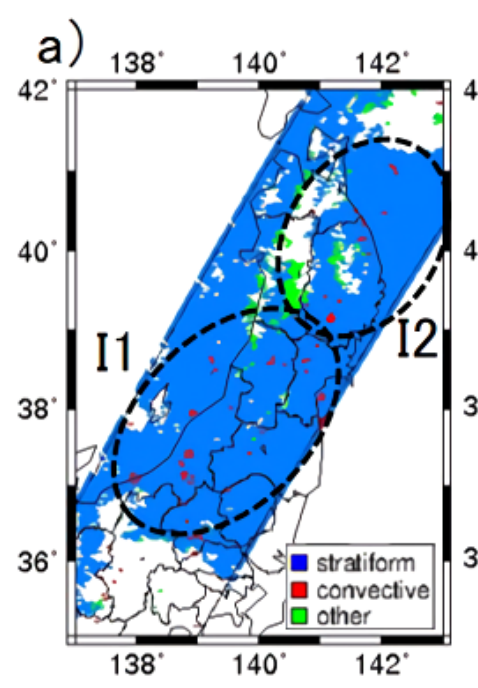

b) $138^{\circ} \quad 140^{\circ} \quad 142$

c)

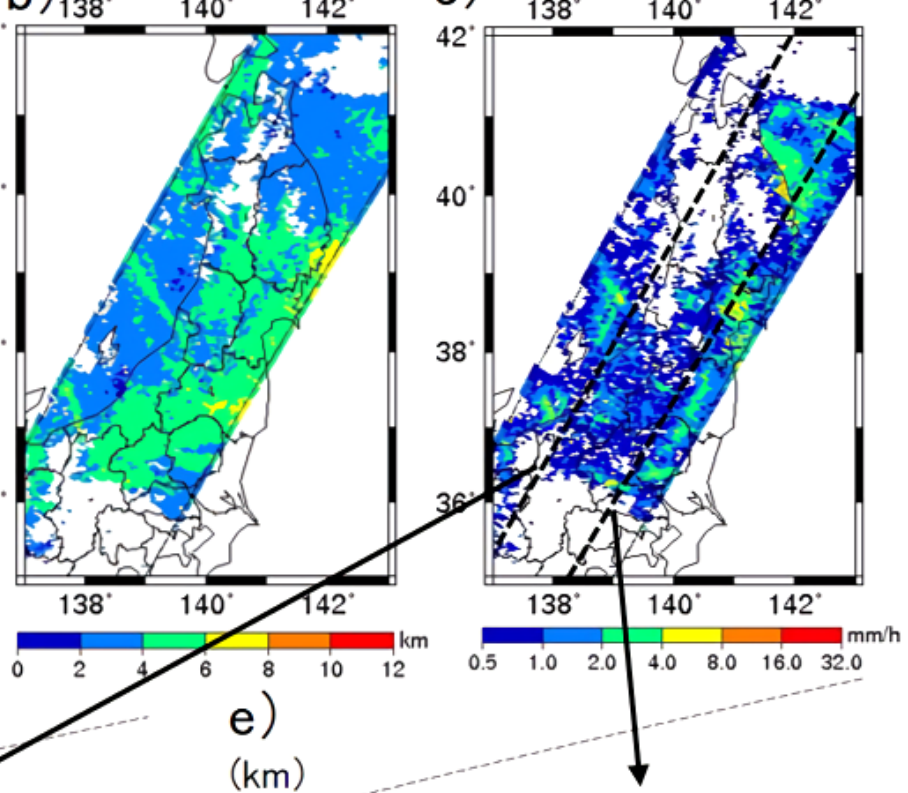

d)

(km)

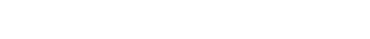




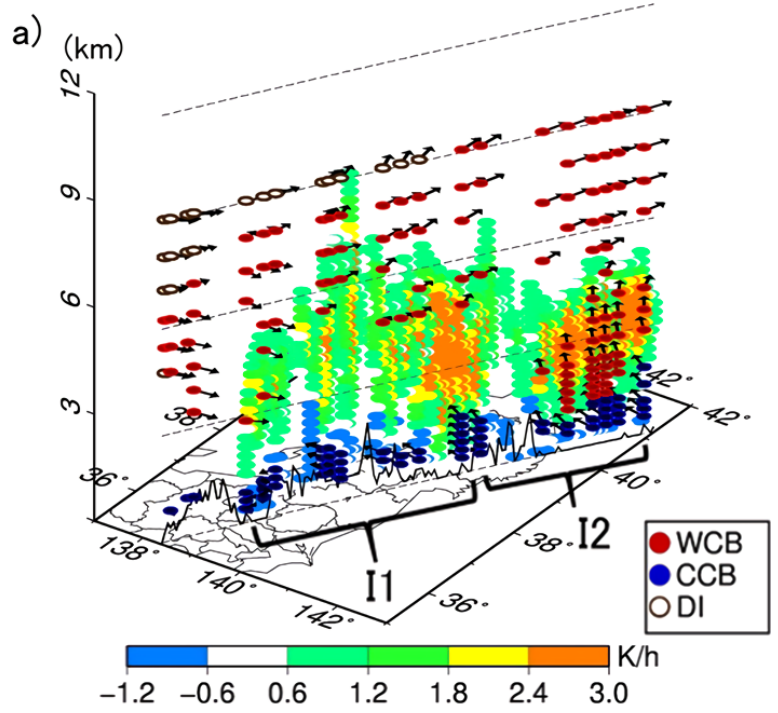

b)

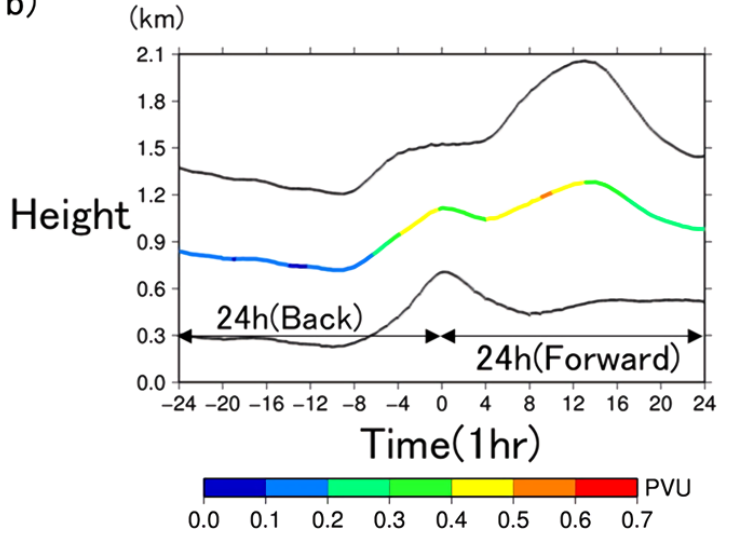

Fig. 14. a) Latent heat release $\left(\mathrm{K} \mathrm{h}^{-1}\right)$, and b) averaged altitude change of parcels categorized as $\mathrm{CCB}$ in Fig. 13e with potential vorticity (colored line with legend, PVU). The black lines indicated the range of standard deviation of the altitude.

in Fig. 13e. During the passage of the cyclone center along the east coast of the Tohoku area, PV increased as the CCB increased its altitude below the WCB. This tendency indicates the strengthening of surface-level cyclonic rotation to intrude $\mathrm{CCB}$ southwestward behind the cyclone center. According to the temporal change in the surface pressure and wind vector after the cyclone center moved away from the mainland on March 11, strong northerly to westerly surface winds of more than $10 \mathrm{~m} \mathrm{~s}^{-1}$ prevailed along the coastal areas of the Kanto and Tokai Districts (figures omitted). These features support this case study and previous studies (Schemm and Wernli 2014; Hart et al. 2017) that show cloud-heat areas in the occluding cyclone are sometimes associated with acceleration of cyclonic rotation and windy weather from CCB intrusion.

\section{Summary and discussion}

Daily-scale nationwide heavy precipitation associated with winter extratropical cyclones causes avalanches in the mountains or sudden heavy snow/rains in the cities; however, the mechanisms regarding the cyclone structure have not been investigated in Japan fully using observational evidence. This study analyzed the relationships between mesoscale precipitation systems and cyclone structures using the conveyor belt model concept, using state-of-art space-born radar data by GPM-CO-DPR that could capture the composition of mesoscale systems embedded in midlatitude synoptic disturbances. First, 50 heavy precipitation events were identified by TAP measured at 137 points with gauge underestimates corrected for solid precipitation from the beginning of GPM observation. The TAP orders at individual stations and with spatially averaged scores in the upper $10 \%$ of ranked cases identified heavy events. The climatology of winter precipitation in Japan was attributed to WMs along the coasts of the SJ or backbone ranges. However, even by considering the gauge measurement deficit that could increase WM precipitation, traveling extratropical cyclones where mature stages were dominant cause most nationwide heavy precipitation events. They tend to appear in late winter to spring, such as March and April, but were not always explosive cyclones, as defined by Sanders and Gyakum (1980).

DPR crossed over precipitation areas for 33 of 50 cases, and several cases providing long cross-sections over specific precipitation areas were chosen for indepth analysis. To identify the origin and routes of airstreams (conveyor belts) associated with precipitation systems identified by DPR observation, 24 (48) $\mathrm{h}$ forward (back) trajectory analysis was performed on ERA5 data originating from the DPR cross-section. By the thresholds of the starting and ending levels, pressure differences, humidity, and the direction of parcels and WCB, CCB, and DI airstreams were objectively identified. This study modified some thresholds of previous studies to increase the airstream candidates for nominated cases. We speculate that nominated cases were not always representative of traditional occluding cyclones because we nominated cases based on the amount of surface precipitation with a DPR-matching opportunity. A comparison study of cyclone structures using DPR data with other storm track regions, such as the North Atlantic, is 
anticipated in the future.

In a case study for first-ranked precipitation events, hourly precipitation variability with a heavy TAP record in western Japan was strongly affected by the domination of the conveyor belts above, according to the passage of SCCs. The WCB intrusion ahead of the cyclone center started to increase hourly precipitation without increasing CAPE, then an extreme precipitation rate occurred as the DI prevailed with a high CAPE. A band-shaped convective system contributed to the sudden increase/termination of precipitation. The tendency was unchanged at a mountain range foot station facing windward, indicating that orographic effects were not the primary cause of precipitation rate changes. These results indicate that conveyor belt activities strongly affect the gauge-measured hourly precipitation changes according to the movement/ development of a cyclone, even in mountainous areas.

To diagnose differences in the precipitation system within a cyclone because of different components of the airstream, such as in the front with the WCB over CCB, in the center with the DI over the WCB, and in the rear covered by cloud heads with the $\mathrm{CCB}$, three SCC cases with different DPR observation passes were selected. In an area ahead of the cyclone center, continuous stratiform precipitation occurred and relatively high elevations were observed, with the lower WCB ascended over the CCB, both intruded from the east in the south. Besides, another upper level WCB was recognized over the stratiform clouds. According to the case study around the cyclone center (case $\beta$ ), this upper WCB was expected to ascend by precursor convective precipitation cells associated with the DI over the WCB. Stratiform precipitation at the comma-head clouds in case $\gamma$ was thicker and composed between the two WCBs with various levels/ orientations, and large latent heat release in the upper level was detected with heat absorption at the bottom. Most conceptual conveyor belt models illustrate a simple-single intrusion of the WCB that separates in different directions over the CCB (Schultz and Vaughan 2011). The DPR observation identified that the allocation of convective and stratiform systems caused various WCBs. Further analysis should diagnose the contribution of convective areas near the cyclone center to transport warm moist areas over stratiform areas around Japan regarding mechanisms of deep warm-frontal zones (Martin 1998) or trowalwarm-front structures (Grim et al. 2007).

Upper stratiform precipitation as observed by the DPR tends to be composed of solid particles in cold seasons with near-surface evaporation at the bottom (as supported by negative latent heating signals in Fig. 14a). Ueno et al. (2019) identified a large overestimation in Global Satellite Mapping of Precipitation data in the case of extratropical cyclones attributed to high-level wide-ranging scattering with stratiform clouds, and features observed in cases $\alpha$ and $\gamma$ are consistent with their results. The case study might assess the cause of bias in satellite precipitation estimations by the microwave passive sensors. However, DPR still has challenges to capture light-to-moderate snowfall over coastal mountains (Aoki and Shige 2021), and careful diagnosis of precipitation profiles are required in cases of heavy snowfall.

Multiple convective clouds around the cyclone center with the DI over the WCB were another critical characteristic causing heavy precipitation rates. The upper front originally illustrated by the classical model (Browning and Monk 1982) was idealized to distinguish surface fronts. This study demonstrated that DI not only causes the upper front but might deform the rear parts of the cyclone system by initiating mesoscale convective areas, and some parts will develop into a band-shaped precipitation system (Fig. 5f). Such band-shaped formation was observed in many cases in Table 1, of which many stretched along the direction of the DI. Kato (2006) also addressed the critical function of mid-level dry air intruded with a cold front behind a cyclone to maintain the condition of convective instability. Besides, limitations exist in assessing the cause of individual convective clouds using the parameters derived from the products of objective analysis data such as ERA5. Further numerical simulation with downscaling could diagnose the formation process of band-shaped precipitation systems in cases of occluding cyclones using DI.

Winter 2019/20 was extremely warm in Japan, and the frequent passage of extratropical cyclones caused warm advection with rain-on-snow in the mountains, especially in central and southwestern Japan. Many cyclones entered from the SJ, and some were accompanied by an occluded or stationary front. Table 1 also lists non-SCCs without extreme developments, which were not treated in this study. The accumulation of DPR observations will provide more opportunities for a comprehensive analysis of meso-systems with cyclones in Japan.

\section{Acknowledgments}

This research was carried out under collaborative studies between the University of Tsukuba and JAXA on satellite precipitation data improvement. DPR products including precipitation type, echo-top height, 
precipitation intensity and latent heat release, were provided by JAXA, and weather chart and radar images were provided by JMA. ERA5 objective analysis data were provided by ECMWF. We used MTSAT-2 data received by the JMA, Weathernews Inc., and Takeuchi Lab; given to the Earthquake Research Institute and Institute of Environment Science, University of Tokyo; and processed and released by the Center for Environmental Remote Sensing, Chiba University. We used Himawari-8 data received by the Center for Environmental Remote Sensing, Chiba University. The authors are grateful to Dr. M. Yamamoto (RESTEC) and Dr. S. Sugimoto (JAMSTEC) for their constructive comments regarding satellite and ERA5 data analysis.

\section{References}

Akiyama, S., S. Shige, M. K. Yamamoto, and T. Iguchi, 2019: Heavy ice precipitation band in an oceanic extratropical cyclone observed by GPM/DPR: 1. A case study. Geophys. Res. Lett., 46, 7007-7014.

Ando, N., and K. Ueno, 2015: Occurrence tendency of heavy rainfall or snowfall in the inland district of Japan in winter. J. Japanese Soc. Snow and Ice, 77, 397-410.

Aoki, S., and S. Shige, 2021: Large precipitation gradients along the south coast of Alaska revealed by spaceborne radars. J. Meteor. Soc. Japan, 99, 5-25.

Araki, K., 2019: Study on heavy snowfall associated with "South-Coast Cyclones": Present state and future work. Meteor. Res. Notes, 241, 605-614.

Araki, K., and M. Murakami, 2015: Numerical simulation of heavy snowfall and the potential role of ice nuclei in cloud formation and precipitation development. CAS/ JSC WGNE Res. Activ. Atmos. Oceanic Modell., 45, 4.03-4.04.

Awaka, J., M. Le, V. Chandrasekar, N. Yoshida, T. Higashiuwatoko, T. Kubota, and T. Iguchi, 2016: Rain type classification algorithm module for GPM DualFrequency Precipitation Radar. J. Atmos. Oceanic Technol., 33, 1887-1898.

Bailey, C. M., G. Hartfield, G. M. Lackmann, K. Keeter, and S. Sharp, 2003: An objective climatology, classification scheme, and assessment of sensible weather impacts for Appalachian cold-air damming. Wea. Forecasting, 18, 641-661.

Bechtold, P., N. Semane, P. Lopez, J.-P. Chaboureau, A. Beljaars, and N. Bormann, 2014: Representing equilibrium and nonequilibrium convection in large-scale models. J. Atmos. Sci., 71, 734-753.

Browning, K. A., 1986: Conceptual models of precipitation systems. Wea. Forecasting, 1, 23-41.

Browning, K. A., 1990: Organization of clouds and precipitation in extratropical cyclones. Extratropical Cyclones. The Erik Palmén Memorial Volume. Newton, C. W., and E. O. Holopainen (eds.), Amer. Meteor. Soc., Boston, 129-153.

Browning, K. A., 1997: The dry intrusion perspective of extra-tropical cyclone development. Meteor. Appl., 4, 317-324.

Browning, K. A., and G. A. Monk, 1982: A simple model for the synoptic analysis of cold fronts. Quart. J. Roy. Meteor. Soc., 108, 435-452.

Catto, J. L., L. C. Shaffrey, and K. I. Hodges, 2010: Can climate models capture the structure of extratropical cyclones? J. Climate, 23, 1621-1635.

Crespo, J. A., and D. J. Posselt, 2016: A-Train-based case study of stratiform-convective transition within a warm conveyor belt. Mon. Wea. Rev., 144, 2069-2084.

Fujibe, F., 1990: Climatology of the coastal front in the Kanto Plain. Pap. Meteor. Geophys., 41, 105-128.

Goodison, B. E., P. Y. T. Louie, and D. Yang, 1998: WMO solid precipitation measurement intercomparison: Final report. Instruments and Observing Methods Report, No. 67, WMO/TD No. 872, World Meteorological Organization, $318 \mathrm{pp}$. [Available at https:// globalcryospherewatch.org/bestpractices/docs/ WMOtd872.pdf.]

Grim, J. A., R. M. Rauber, M. K. Ramakurthy, B. F. Jewett, and M. Han, 2007: High-resolution observations of the trowal-warm-frontal region of two continental winter cyclones. Mon. Wea. Rev., 135, 1629-1646.

Han, M., R. M. Rauber, M. K. Ramamurthy, B. F. Jewett, and J. A. Grim, 2007: Mesoscale dynamics of the trowal and warm-frontal regions of two continental winter cyclones. Mon. Wea. Rev., 135, 1647-1670.

Hart, N. C. G., S. L. Gray, and P. A. Clark, 2017: Sting-jet windstorms over the North Atlantic: Climatology and contribution to extreme wind risk. J. Climate, 30, 5455-5471.

Hersbach, H., B. Bell, P. Berrisford, S. Hirahara, A. Horányi, J. Muñoz-Sabater, J. Nicolas, C. Peubey, R. Radu, D. Schepers, A. Simmons, C. Soci, S. Abdalla, X. Abellan, G. Balsamo, P. Bechtold, G. Biavati, J. Bidlot, M. Bonavita, G. D. Chiara, P. Dahlgren, D. Dee, M. Diamantakis, R. Dragani, J. Flemming, R. Forbes, M. Fuentes, A. Geer, L. Haimberger, S. Healy, R. J. Hogan, E. Hólm, M. Janisková, S. Keeley, P. Laloyaux, P. Lopez, C. Lupu, G. Radnoti, P. de Rosnay, I. Rozum, F. Vamborg, S. Villaume, and J.-N. Thépaut, 2020: The ERA5 global reanalysis. Quart. J. Roy. Meteor. Soc., 146, 1999-2049.

Hirata, H., R. Kawamura, M. Kato, and T. Shinoda, 2016: Response of rapidly developing extratropical cyclones to sea surface temperature variations over the western Kuroshio-Oyashio confluence region. J. Geophys. Res.: Atmos., 121, 3843-3858.

Hobbs, P. V., 1978: Organization and structure of clouds and precipitation on the mesoscale and microscale in cyclonic storms. Rev. Geophys., 16, 741-755.

Hou, A. Y., R. K. Kakar, S. Neeck, A. A. Azarbarzin, C. D. 
Kummerow, M. Kojima, R. Oki, K. Nakamura, and T. Iguchi, 2014: The Global Precipitation Measurement mission. Bull. Amer. Meteor. Soc., 95, 701-722.

Iguchi, T., S. Seto, R. Meneghini, N. Yoshida, J. Awaka, M. Le, V. Chandrasekar, and T. Kubota, 2017: GPM/DPR level-2 algorithm theoretical basis document. JAXANASA Tech. Rep., 81 pp.

Ito, T., and K. Ueno, 2016: Changes in precipitation distribution associated with abrupt warming in winter at the end of the 1980s and the effects of surface pressure patterns. J. Geogr., 125, 185-199.

Izumi, K., T. Matsumoto, I. Kamiishi, K. Sasaki, T. Takahashi, and H. Moriyama, 2015: Snow-related disasters in Kanto-Koshinetsu due to the heavy snow in February 2014. J. Japanese Soc. Snow and Ice, 77, i-ii.

Japan Aerospace Exploration Agency, 2017: Spectral latent heating (SLH) for GPM: Algorithm theoretical basis document. Algorithm, Ver. 7, 19 pp. [Available at https://www.eorc.jaxa.jp/GPM/doc/algorithm/170630 SLH_ATBDfinal.pdf.]

Kato, T., 2006: Structure of the band-shaped precipitation system inducing the heavy rainfall observed over northern Kyushu, Japan on 29 June 1999. J. Meteor. Soc. Japan, 84, 129-153.

Kobayashi, K., S. Shige, and M. K. Yamamoto, 2018: Vertical gradient of stratiform radar reflectivity below the bright band from the tropics to the extratropical latitudes seen by GPM. Quart. J. Roy. Meteor. Soc., 144, 165-175.

Kodama, C., B. Stevens, T. Mauritsen, T. Seiki, and M. Satoh, 2019: A new perspective for future precipitation change from intense extratropical cyclones. Geophys. Res. Lett., 46, 12435-12444.

Le, M., and V. Chandrasekar, 2013: Precipitation type classification method for dual-frequency precipitation radar (DPR) onboard the GPM. IEEE Trans. Geosci. Remote Sens., 51, 1784-1790.

Le, M., V. Chandrasekar, and S. Biswas, 2017: An algorithm to identify surface snowfall from GPM DPR observations. IEEE Trans. Geosci. Remote Sens., 55, 40594071.

Martin, J. E., 1998: The structure and evolution of a continental winter cyclone. Part I: Frontal structure and the occlusion process. Mon. Wea. Rev., 126, 303-328.

Martínez-Alvarado, O., L. H. Baker, S. L. Gray, J. Methven, and R. S. Plant, 2014: Distinguishing the cold conveyor belt and sting jet airstreams in an intense extratropical cyclone. Mon. Wea. Rev., 142, 2571-2595.

Matsuo, T., 1984: The study of melting of snowflakes in the atmosphere. Tech. Rep. Meteor. Res. Inst., vol. 8, 1020 (in Japanese).

Matsuo, T., and Y. Sasyo, 1982: Melting of snow pellets in the atmosphere. Pap. Meteor. Geophys., 33, 55-64.

Matsushita, H., and K. Ishida, 2016: Characteristics of snow avalanche release in forests during a heavy snowfall event. Proceedings of the International Snow Science
Workshop, Breckenridge, Colorado, 556-560.

Moriyama, H., S. Sase, L. Okushima, and M. Ishii, 2015: Which design constraints apply to a pipe-framed greenhouse? From perspective of structural engineering, meteorological conditions, and wind engineering. Japan Agric. Res. Quart., 49, 1-9.

Murphy, A. M., R. M. Rauber, G. M. McFarquhar, J. A. Finlon, D. M. Plummer, A. A. Rosenow, and B. F. Jewett, 2017: A microphysical analysis of elevated convection in the comma head region of continental winter cyclones. J. Atmos. Sci., 74, 69-91.

Naud, C. M., J. F. Booth, M. Lebsock, and M. Grecu, 2018: Observational constraint for precipitation in extratropical cyclones: Sensitivity to data sources. J. Appl. Meteor. Climatol., 57, 991-1009.

Novak, D. R., B. A. Colle, and A. R. Aiyyer, 2010: Evolution of mesoscale precipitation band environments within the comma head of northeast U.S. cyclones. Mon. Wea. Rev., 138, 2354-2374.

Rauber, R. M., J. Wegman, D. M. Plummer, A. A. Rosenow, M. Peterson, G. M. McFarquhar, B. F. Jewett, D. Leon, P. S. Market, K. R. Knupp, J. M. Keeler, and S. M. Battaglia, 2014: Stability and charging characteristics of the comma head region of continental winter cyclones. J. Atmos. Sci., 71, 1559-1582.

Raveh-Rubin, S., 2017: Dry intrusions: Lagrangian climatology and dynamical impact on the planetary boundary layer. J. Climate, 30, 6661-6682.

Sanders, F., and J. R. Gyakum, 1980: Synoptic-dynamic climatology of the "bomb". Mon. Wea. Rev., 108, 1589-1606.

Sawada, M., R. Anzai, and K. Ueno, 2019: Continuous heavy precipitation with a winter occluding cyclone captured by GPM satellite in central Japan. Tsukuba Geoenviron. Sci., 15, 1-11.

Schemm, S., and H. Wernli, 2014: The linkage between the warm and the cold conveyor belts in an idealized extratropical cyclone. J. Atmos. Sci., 71, 1443-1459.

Schultz, D. M., and G. Vaughan, 2011: Occluded fronts and the occlusion process: A fresh look at conventional wisdom. Bull. Amer. Meteor. Soc., 92, 443-466.

Seto, S., T. Iguchi, R. Meneghini, J. Awaka, T. Kubota, T. Masaki, and N. Takahashi, 2021: The precipitation rate retrieval algorithms for the GPM Dual-frequency Precipitation Radar. J. Meteor. Soc. Japan, 99, 205237.

Shapiro, M. A., and D. Keyser, 1990: Fronts, jet streams and the tropopause. Extratropical Cyclones. The Erik Palmén Memorial volume. Newton, C. W., and E. O. Holopainen (eds.), Amer. Meteor. Soc., Boston, 167191.

Shige, S., Y. N. Takayabu, W.-K. Tao, and D. E. Johnson, 2004: Spectral retrieval of latent heating profiles from TRMM PR data. Part I: Development of a modelbased algorithm. J. Appl. Meteor., 43, 1095-1113.

Shige, S., Y. N. Takayabu, W.-K. Tao, and C.-L. Shie, 2007 : 
Spectral retrieval of latent heating profiles from TRMM PR data. Part II: Algorithm improvement and heating estimates over tropical ocean regions. J. Appl. Meteor. Climatol., 46, 1098-1124.

Skofronick-Jackson, G., W. A. Petersen, W. Berg, C. Kidd, E. F. Stocker, D. B. Kirschbaum, R. Kakar, S. A. Braun, G. J. Huffman, T. Iguchi, P. E. Kirstetter, C. Kummerow, R. Meneghini, R. Oki, W. S. Olson, Y. N. Takayabu, K. Furukawa, and T. Wilheit, 2017: The Global Precipitation Measurement (GPM) mission for science and society. Bull. Amer. Meteor. Soc., 98, 1679-1695.

Sprenger, M., and H. Wernli, 2015: The LAGRANTO Lagrangian analysis tool - version 2.0. Geosci. Model Dev., 8, 2569-2586.

Steenburgh, W. J., and S. Nakai, 2020: Perspectives on seaand lake-effect precipitation from Japan's "gosetsu chitai”. Bull. Amer. Meteor. Soc., 101, E58-E72.

Szeto, K. K., C. A. Lin, and R. E. Stewart, 1988: Mesoscale circulation forced by melting snow. Part I: Basic simulations and dynamics. J. Atmos. Sci., 45, 1629-1641.

Takahashi, T., T. Chiba, and K. Nakamura, 2016: Structural damage caused by rain-on-snow load in Japan. Proceedings of 8th International Conference on Snow Engineering, 173-178.

Takano, I., 2002: Analysis of an intense winter extratropical cyclone that advanced along the south coast of Japan. J. Meteor. Soc. Japan, 80, 669-695.

Takeda, T., N. Moriyama, and Y. Iwasaka, 1976: A case study of heavy rain in Owase area. J. Meteor. Soc. Japan, 54, 32-41.
Ueno, K., W. Mito, R. Kanai, Y. Ueji, A. Inami, K. Suzuki, H. Kobayashi, I. Tamagawa, M. K. Yamamoto, and S. Shige, 2019: Distribution of precipitation depending on synoptic scale disturbances with satellite estimate comparisons in the Japanese Alps area during warm seasons. J. Geogr., 128, 31-47.

Wernli, H., and H. C. Davies, 1997: A Lagrangian-based analysis of extratropical cyclones. I: The method and some applications. Quart. J. Roy. Meteor. Soc., 123, 467-489.

Yamaji, M., H. G. Takahashi, T. Kubota, R. Oki, A. Hamada, and Y. N. Takayabu, 2020: 4-year climatology of global drop size distribution and its seasonal variability observed by spaceborne Dual-frequency Precipitation Radar. J. Meteor. Soc. Japan, 98, 755-773.

Yamamoto, Y., K. Ichii, A. Higuchi, and H. Takenaka, 2020: Geolocation accuracy assessment of Himawari-8/ AHI imagery for application to terrestrial monitoring. Remote Sens., 12, 1372, doi:10.3390/rs12091372.

Yamazaki, A., M. Honda, and A. Kuwano-Yoshida, 2015: Heavy snowfall in Kanto and on the Pacific Ocean side of northern Japan associated with western Pacific blocking. SOLA, 11, 59-64.

Yoshida, S., 1959: Study of accumulated snow amount measurements, No. 2. Determination of catching ration and practical usage. J. Meteor. Res.-PRC, 11, 507524.

Zhang, A., Y. Chen, X. Zhang, Q. Zhang, and Y. Fu, 2020: Structure of cyclonic precipitation in the northern Pacific storm track measured by GPM DPR. J. Hydrometeor., 21, 227-240. 